\title{
The Trend Analysis of Various Components of Water Resources System of Ozat River Basin, Gujarat, India
}

\author{
A.M. Paghadal ${ }^{1}$, H.D. Rank $^{2}$, G.V. Prajapati ${ }^{2}$, P.H. Rank ${ }^{3}$, \\ P.S. Pipaliya ${ }^{3}$ and J.S. Pipaliya ${ }^{4}$ \\ ${ }^{1}$ Research Testing and Training Centre (RTTC), Junagadh Agricultural University, \\ Junagadh, Gujarat, India \\ ${ }^{2}$ Department of Soil and Water Engineering, College of Agricultural Engineering and \\ Technology, Junagadh Agricultural University, Junagadh, Gujarat, India \\ ${ }^{3}$ College of Agricultural Engineering and Technology, Junagadh Agricultural University, \\ Junagadh, Gujarat, India \\ ${ }^{4}$ Dharamsinh Desai Institute of Technology, Nadiad, India \\ *Corresponding author
}

\section{Keywords}

Rainfall, Runoff, Groundwater recharge,

Watershed,

Evapotranspiration

Article Info

Accepted:

04 October 2019

Available Online:

10 November 2019

\section{A B S T R A C T}

The trend analysis of various components of various water resources system like rainfall, runoff, evapotranspiration and ground water recharge will help to prepare a future plan for ground water development and management plan for the basin. It will also be helpful for agricultural as well other resources planning. The required shift in cropping pattern can also be judged. The quantity predictions can be achieved to aid managerial and policy action directed towards natural resources management. The seasonal potential evapotranspiration in the Ozat basin was found insignificantly decreasing while crop evapotranspiration significantly increasing indicating that rainfall is increasing due to climatic variability. The average monsoon rainfall of the Ozat basin is found as $730.81 \mathrm{~mm}$. The area weighted rainfall and runoff are found increasing in the basin. The rainfall and runoff is found increasing insignificantly for the entire river basin. The rainfall and runoff both were found increasing respectively in 1 and 3 watersheds of the basin out of 4 . However, rainfall is significantly increasing in 2 watersheds (5G1C4, 5G1C5) while runoff is significantly increasing in 1 watershed (5G1C5) only. The rainfall is observed insignificantly decreasing in 1 watershed (5G1C2). The area weighted rainfall and runoff are found increasing in the basin. The rainfall and runoff is found increasing insignificantly for the entire river basin. 


\section{Introduction}

Agriculture and related sectors, food security, and energy security of India are crucially dependent on the timely availability of adequate amount of water and a conducive climate. The rainfall received in an area is an important factor in determining the amount of water available to meet various demands, such as agricultural, industrial, domestic water supply and for hydroelectric power generation. Global climate changes may influence longterm rainfall patterns impacting the availability of water, along with the danger of increasing occurrences of droughts and floods. The southwest (SW) monsoon, which brings about $80 \%$ of the total precipitation over the country, is critical for the availability of freshwater for drinking and irrigation. Changes in climate over the Indian region, particularly the SW monsoon, would have a significant impact on agricultural production, water resources management and overall economy of the country. The heavy concentration of rainfall in the monsoon months (June-September) results in scarcity of water in many parts of the country during the non-monsoon periods.

In view of the above, a number of studies have attempted to investigate the trend of climatic variables for the Ozat River Basin. These studies have looked at the trends on the regional scales and at the individual stations. This article gives an exhaustive coverage of the reported studies dealing with two variables which are critical in hydrologic studies: rainfall and temperature. Temperature and its changes impact a number of hydrological processes including rainfall and these processes, in turn, also impact temperature (e.g., cooling due to rain/snow).

Due to the uneven distribution of rainfall and the mismatch between water availability and demand, large storage reservoirs are required to redistribute the natural flow in accordance with the requirements of specific regions. The design of hydro-infrastructure is generally based on the assumption that climate is stationary. Changes in rainfall due to global warming will influence the hydrological cycle and the pattern of stream-flows and demands (particularly agricultural), requiring a review of hydrologic design and management practices. Changes in run-off and its distribution will depend on likely future climate scenarios ${ }^{2}$. The trend analysis of rainfall, temperature and other climatic variables on different spatial scales will help in the construction of future climate scenarios. Using this water availability in different watersheds can be assessed in the context of future requirements. (Jain and Kumar, 2012)

Ozat is the most important river of Saurashtra. Ozat river originates from near Visavadar and meets in a Arebian sea. It is situated between latitude of $21^{\circ} \mathrm{N}$ to $22^{\circ} \mathrm{N}$ and longitude of $70^{\circ} \mathrm{E}$ to $71^{\circ} \mathrm{E}$. Its length is $125 \mathrm{~km}$ having catchment area of $3185 \mathrm{~km} 2$ and Dhrafad and Ozat dams are located on this river having 169 $\mathrm{km}^{2}$ and $1138 \mathrm{~km}^{2}$ catchment area respectively.

Abajal and Popatdi are right bank tributaries, and Uben and Utavali are left bank tributaries of this river. The climate of the project area can be classified as tropical and sub-tropical. January is the coldest month with mean monthly temperature varying from $4^{\circ} \mathrm{C} \& 15^{\circ} \mathrm{C}$ and maximum monthly temperature varies between $40^{\circ} \mathrm{C}$ and $46^{\circ} \mathrm{C}$ in the month of May. Agriculture is the main occupation in the area. Groundwater is the main source of irrigation in study area. Major area falls under rain fed agriculture with groundnut and cotton as main kharif crops and wheat, cumin, gram, coriander, garlic and onion as main winter crops. The short duration varieties of crops like sesame, groundnut, green gram and black gram are sown by the farmers during the summer season. 


\section{Materials and Methods}

The historical hydro-metrological data (19812010) were collected from the State Water data Centre, Gandhinagar. The historical groundwater level data were obtained from Central Groundwater Board, Ahmedabad. Mean temperature of the day was obtained by taking average of the maximum and minimum temperature of the day. The annual average of daily maximum, minimum and mean temperature was taken as average of respective 365 days values during the particular year. Similarly, the monthly and seasonal average of daily maximum, minimum and mean temperature was taken as average of days of respective periods.

The time series analysis of the water balance components on the basin scale carried out using the standard method as described by Kendall (1975) and Gilbert along with best fit trend analysis.

\section{Mann-Kendall analysis}

The Mann-Kendall test is a non-parametric test for identifying trend in time data. The test compares the relative magnitude so f sample data rather than the value themselves (Gilbert, 1987). One benefit of this test is that the data need not to any particular distribution.

Moreover, data reported as non-detects can be included by assigning them a common value that is smaller than the smallest measured value in the dataset. The procedure that could be described in the subsequent paragraphs assumes that there exists only one data value per time period.

The temperature data values were evaluated as an ordered time series. Each data value was compared to all subsequent data values. The initial value of the Mann- Kendall statistic, S, was assumed to be 0 (e.g., no trend). If a data value from a later time period was higher than a data value from an earlier time period, $\mathrm{S}$ was incremented by 1 . On the other hand, if the data value from a later time period was lower than a data value sampled earlier, $S$ was decremented by 1 . The net result of all such increments and decrements gave the final value of $\mathrm{S}$.

Mann-Kendall statistic (S) was calculated by following Eq.3.1 (Kendall and Gibbons, 1990).

$$
S=\sum_{k=1}^{n-1} \sum_{j=k+1}^{n} \quad \operatorname{sign}\left(x_{i}-x_{k}\right) \ldots(3.1)
$$

Where,

Sign $\left(\mathrm{x}_{\mathrm{j}}-\mathrm{x}_{\mathrm{k}}\right)=1,0$ and -1 , if $\mathrm{x}_{\mathrm{j}}>\mathrm{x}_{\mathrm{k}}, \mathrm{x}_{\mathrm{j}}=\mathrm{x}_{\mathrm{k}}$ and $\mathrm{x}_{\mathrm{j}}<\mathrm{x}_{\mathrm{k}}$ respectively;

$\mathrm{n}=$ number of data points in time series

A very high positive value of $\mathrm{S}$ was an indicator of an increasing trend, and a very low negative value indicated a decreasing trend. However, it was necessary to compute the probability associated with $\mathrm{S}$ and the sample size, $\mathrm{n}$, to statistically quantify the significance of the trend. The variance of $S$, i.e. VAR (S) for each data series was estimated by the Eq.3.2.

\section{$\operatorname{VAR}(S)$ \\ $=\frac{1}{18} \times\left[(n(n-1))(2 n+5)-\sum_{p=1}^{m} t_{p}\left(t_{p}-1\right)\left(2 t_{p}+5\right)\right]_{\ldots . .(}$}

3.2)

Where,

$\mathrm{n}=$ number of data points, $\mathrm{m}$ is the number of tied groups (a tied group was a set of sample data having the same value);

$\mathrm{tp}=$ number of data points in the $\mathrm{p}$ group. 
The normalized test statistic $\mathrm{Z}$ was computed as follows.

$$
\begin{aligned}
& Z=\left\{[s-1] /[\operatorname{VAR}(S)]^{1 / 2}\right\} \text { if } S>0 \\
& =0 \text { if } \mathrm{S}=0 \\
& =\left\{[s-1] /[\operatorname{VAR}(S)]^{1 / 2}\right\} \text { if } S<0 \ldots(3.3)
\end{aligned}
$$

If $\mathrm{Zcal}>\mathrm{O}$ and $\mathrm{Zcal}>\mathrm{Ztab} \quad$ where, $\mathrm{Ztab}=$ $3.090, \quad 2.326, \quad 1.645, \quad 0.282$, the trend considered as increasing and if Zcal $<0$ and Zcal $>$ Ztab the trend was considered as increasing and if Zcal $<0$ and $-\mathrm{Zcal}>\mathrm{Ztab}$ at 0.1 percent, 1 percent, 5 percent and 10 percent respectively.

\section{Sen's slope method}

One of the difficulties encountered in the interpretation of environmental field data was the quantification of trends (e.g., calculation of slope) and demonstration that this estimation of trend was statistically different from zero. The focus here was on one nonparametric method used in determining the presence of slope and is known simply as Sen's Nonparametric Estimator of Slope.

Several tests were available for the detection and/or quantification of trends. The first step in analyzing any data set, however, was to graph the data, usually as a function of space or location. Graphical representations of data facilitated observation of general trends and cycles which might assist in the selection of an appropriate statistical test.

Sen's method for the estimation of slope required a time series of equally spaced data. Sen's method proceeded by calculating the slope as a change in measurement per change in time. The true slope of an existing trend (as change per year) was being determined using the Sen's nonparametric method.
The slope $m_{i}$ between two values of pair of all data was estimated as follows, (Sen, 1968).

$m_{i}=\frac{\left(x_{i}-x_{k}\right)}{(j-k)} \ldots . .(3.4)$

Where,

$\mathrm{k}=1,2,3, \ldots .(\mathrm{n}-1)$

$\mathrm{j}=\mathrm{k}+1=2,3, \ldots . . \mathrm{n} ;$

$\mathrm{I}=1$ to $\mathrm{N}[\mathrm{N}=\mathrm{n}(\mathrm{n}-1) / 2]$

The Sen's estimator of slope was estimated using the following expression $\mathrm{m}=\mathrm{m}_{(\mathrm{N}+1) / 2}$ if $\mathrm{N}$ is odd

$m=\frac{1}{2}\left(m_{N / 2}+m_{(N+2)+1}\right)$ if $\mathrm{N}$ is even...(3.5)

Sen's method also allowed for determination of whether the median slope was statistically different from zero. A confidence interval was developed by estimating the rank for the upper and lower confidence interval and using the slopes corresponding to these ranks to define the actual confidence interval for slope. For a two-sided confidence interval about the median slope, first $\mathrm{Z}$ statistic was found for a two-tailed normal distribution test. For example, the two-sided confidence interval of desired $a=5$ percent level, $Z(1-0.05 / 2)=$ $\mathrm{Z} 0975=1.96$ was found from standard statistical tables. Next, the variance of the Mann-Kendall statistic (VAR(S)) was developed by Kendall (1975) was estimated using Eq. 3.2.

To estimate the range of ranks for the specified confidence interval, $\mathrm{C}$ was found using Eq. 3.6.

$C_{\propto}=Z_{1-\propto / 2} \times \sqrt{\operatorname{VAR(S)}} \ldots \ldots$ (3.6)

The ranks of the lower $\left(\mathrm{M}_{1}\right)$ and upper $\left(\mathrm{M}_{2}+1\right)$ confidence limits was estimated using Eg. 3.7, 
$M 1=\frac{N^{s}-C_{\propto}}{2}$

$M 2+1=\frac{N^{r}+C_{\mathrm{x}}}{2} \ldots \ldots$

Finally, the slopes corresponding to $\mathrm{M}_{1}$, and $\mathrm{M}_{2}+1$ as the lower and upper confidence limits respectively should be chosen. The statistically significance of the slope was estimated by Eq. 3.2 was tested at desired $\mathrm{a}=$ 1 percent and 5 percent.

The slope was considered as significant if zero did not lie between slope values ranked at $\mathrm{M}_{1}$, and $\mathrm{M}_{2}+1$.

The care was taken for the median slope that it was statistically different from zero (for the selected confidence interval) i.e. the zero did not lie between the upper and lower confidence limits.

\section{Best fit trend line}

The best fit trend line slope was taken as average change per year in cases where the trend could be assumed to be linear.

$$
f(t)=(m t+c) \ldots . .3 .8
$$

Where,

$\mathrm{m}=$ slope

$\mathrm{c}=$ constant.

\section{Results and Discussion}

The rainfall, runoff and evapotranspiration are the three most influencing water balance components on the groundwater recharge.

Therefore, the trend analyses of the rainfall, runoff, evapotranspiration and groundwater recharge were assessed.

\section{Rainfall and runoff}

The daily runoff for each watershed of the basin was estimated using SWAT and SCSCN techniques for the period (1981-2010). The $\mathrm{CN}$ of the basin was obtained as 67.5 using remote sensing and GIS with ground truth information of the basin. The monsoon runoff was obtained by summing up the daily runoff values during the monsoon period (June-September).

The rainfall and runoff observed during 19812010 are depicted in Fig. 1, 2, 3, 4 for 5G1C2, 5G1C3, 5G1C4, 5G1C5 respectively and Fig. 5 for the entire basin. The Mann-Kendall and Sen's slope statistics along with statistical parameter for the monsoon rainfall and runoff for the different watershed and basin were found as presented in Table 1 and 2 .

\section{Trend analysis monsoon rainfall and runoff by SCS-CN}

\section{Watershed 5G1C2}

The watershed is having an area of 521.13 $\mathrm{km} 2$. The highest monsoon rainfall and runoff depth in watershed 5G1C2 were found as $1261.5 \mathrm{~mm}$ and $923.3 \mathrm{~mm}$ respectively. Similarly, the lowest monsoon rainfall of 28.0 $\mathrm{mm}$ with the lowest runoff depth of $0.0 \mathrm{~mm}$ was found for watershed $5 \mathrm{G} 1 \mathrm{C} 2$. The mean rainfall depth was found as $472.0 \mathrm{~mm}$ while the median of the rainfall was found as 446.3 $\mathrm{mm}$ for the watershed 5G1C2. The closeness in mean and median values indicated that the monsoon rainfall time series is nearly normally distributed. The mean and median of the runoff depth were found as $159.3 \mathrm{~mm}$ and $129.8 \mathrm{~mm}$ respectively for the watershed 5G1C2. The difference between mean and median and the value of skewness coefficient indicated that the runoff data series are not normally distributed. 
The coefficient of skewness was found as 0.9 for the rainfall time series data and 2.9 for the runoff time series data for the watershed 5G1C2. Similarly, the kurtosis coefficient was found as 1.1 for the rainfall time series data 11.0 for the runoff time series data for the watershed $5 \mathrm{G} 1 \mathrm{C} 2$. The coefficient of variation in time series data of rainfall was found as 62.0 while that of for the time series of runoff was found as 114.3 for the watershed $5 \mathrm{G} 1 \mathrm{C} 2$.

The coefficient of variation in runoff was found higher as compare to that of rainfall indicating that runoff is influenced by uncertainty in rainfall magnitude as well as its temporal distribution during the monsoon period. The data of rainfall and runoff presented in Table 2 and 3 also supports the same.

The Mann-Kendall statistics showed that the rainfall (Table 3 ) is decreasing non-significant for the watershed 5G1C2. The slope of the best fit trend line of rainfall was observed as $6.31 \mathrm{~mm}$ per year while that of estimated by Sen's method was found as $-2.806 \mathrm{~mm}$ per year.

The close agreement was not found between the slopes of the best fit trend line and estimated by Sen's method. The Sen's slope was found insignificant for watershed. It seems that there are no much change in rainfall of watersheds $5 \mathrm{G} 1 \mathrm{C} 2$.

The Mann-Kendall statistics for the runoff data series (Table 4) showed that runoff is increasing non-significantly in watershed. The same trend was seen by the Sen's slope $(1.156 \mathrm{~mm} /$ year) method also. Even if the rainfall is in decreasing trend, the runoff is increasing. However, as per the slope of the best fit trend line of runoff $(-2.50 \mathrm{~mm}$ per year), the runoff is also found in decreasing trend for watershed $5 \mathrm{G} 1 \mathrm{C} 2$. There may be no significant change in runoff from watershed.

\section{Watershed 5G1C3}

The entire watershed was consisted of 998.58 $\mathrm{km}^{2}$ area. The highest monsoon rainfall depth in watershed 5G1C3 was found as $2269.8 \mathrm{~mm}$ with runoff depth of $1477.5 \mathrm{~mm}$. Similarly, the lowest monsoon rainfall of $293.5 \mathrm{~mm}$ with the lowest runoff depth of $11.7 \mathrm{~mm}$ was found for watershed $5 \mathrm{G} 1 \mathrm{C} 3$.

The mean of rainfall depth was found as 778.5 $\mathrm{mm}$ while the median of the rainfall was found as $697.5 \mathrm{~mm}$ for the watershed 5G1C3. The difference in mean and median values indicated that the monsoon rainfall time series is not normally distributed. Similarly for the same watershed the mean and median of the runoff data series were found as $241.0 \mathrm{~mm}$ and $183.5 \mathrm{~mm}$. The difference between mean and median and the value of skewness coefficient indicated that the runoff data series are not normally distributed.

The coefficient of skewness was found as 1.7 for the rainfall time series data and 3.3 for the runoff time series data for the watershed 5G1C3. Similarly, the kurtosis coefficient was found as 4.5 for the rainfall time series data 13.7 for the runoff time series data for the watershed $5 \mathrm{G} 1 \mathrm{C} 3$. The coefficient of variation in time series data of rainfall was found as 53.3 while that of for the time series of runoff was found as 115.0 for the watershed 5G1C3. The coefficient of variation in runoff was found higher as compare to that of rainfall indicating that runoff is influenced by uncertainty in rainfall magnitude as well as its temporal distribution during the monsoon period. The data of rainfall and runoff presented in Table 2 and Table 3 also supports the same. The rainfall and runoff data showed that the highest rainfall and runoff are occurred in the same year 1983.

The Mann-Kendall statistics (Table 3) showed that the rainfall is increasing non-significant 
for the watershed 5G1C3 with Sen's slope of $2.321 \mathrm{~mm}$ per year. However, the slope of the best fit trend line of rainfall was observed as $4.15 \mathrm{~mm}$ per year. The close agreement was not found between the slopes of the best fit trend line and estimated by Sen's method. The Sen's slope was found insignificant for watershed. It seems that there are no much change in rainfall of watersheds 5G1C3.

The Mann-Kendall statistics (Table 4) for the runoff data series showed that runoff is increasing non-significantly in watershed. The result is also supported by the Sen's slope of $1.636 \mathrm{~mm} /$ year. However, the slope of the best fit trend line of runoff was observed as -6.84 $\mathrm{mm}$ per year. This indicated that there may not be the significant change in runoff from watershed.

\section{Watershed 5G1C4}

The highest monsoon rainfall depth in watershed 5G1C4 (587.62 km2 area) were found as $1470.7 \mathrm{~mm}$ with highest runoff depth of $856.5 \mathrm{~mm}$. Similarly, the lowest monsoon rainfall of $226.5 \mathrm{~mm}$ with the lowest runoff depth of $10.5 \mathrm{~mm}$ was found for watershed $5 \mathrm{G} 1 \mathrm{C} 4$. The mean of rainfall depth was found as $750.2 \mathrm{~mm}$ while the median of the rainfall was found as $718.8 \mathrm{~mm}$ for the watershed 5G1C4. The closeness in mean and median values with skewness of 0.5 indicated that the monsoon rainfall time series data is nearly normally distributed. The mean and median runoff depths were found as $233.4 \mathrm{~mm}$ and $186.3 \mathrm{~mm}$ respectively. The difference between mean and median and the value of skewness coefficient (1.5) indicated that the runoff data series are not normally distributed.

The coefficient of skewness was found as 0.5 for the rainfall time series data and 1.5 for the runoff time series data for the watershed 5G1C4. Similarly, the kurtosis coefficient was found as -0.5 for the rainfall time series data
2.8 for the runoff time series data for the watershed $5 \mathrm{G} 1 \mathrm{C} 4$. The coefficient of variation in time series data of rainfall was found as 43.8 while that of for the time series of runoff was found as 81.2 for the watershed 5G1C4. The coefficient of variation in runoff was found higher as compare to that of rainfall indicating that runoff is influenced by uncertainty in rainfall magnitude as well as its temporal distribution during the monsoon period. The data of rainfall and runoff presented in Table 2 also supports the same.

The Mann-Kendall statistics (Table 3) showed that the rainfall is increasing significant at $10 \%$ for the watershed $5 \mathrm{G} 1 \mathrm{C} 4$. The slope of the best fit trend line of rainfall was observed as $8.10 \mathrm{~mm}$ per year while that of estimated by Sen's method was found as $11.69 \mathrm{~mm}$ per year. The close agreement was not found between the slopes of the best fit trend line and estimated by Sen's method. In fact, the Sen's slope was found insignificant for watershed. It seems that there are increasing trend in rainfall of watersheds $5 \mathrm{G} 1 \mathrm{C} 4$.

The Mann-Kendall statistics (Table 4) for the runoff data series showed that runoff is increasing non-significantly in watershed. The result is also supported by the slope of best fitted line and Sen's slope method. However, The slope of the best fit trend line of runoff was observed as $0.29 \mathrm{~mm}$ per year while that of estimated by Sen's method was found as $4.52 \mathrm{~mm}$ per year $\mathrm{mm}$ per year for watershed $5 \mathrm{G} 1 \mathrm{C} 4$. There may be no significant change in runoff from watershed.

\section{Watershed 5G1C5}

The highest monsoon rainfall depth in watershed 5G1C5 (1068.90 km2 area) were found $1890.0 \mathrm{~mm}$ with runoff depth of 1007.7 $\mathrm{mm}$. Similarly, the lowest monsoon rainfall of $211.3 \mathrm{~mm}$ with the lowest runoff depth of 5.5 $\mathrm{mm}$ was found. The coefficient of skewness 
was found as 0.9 for the rainfall time series data and 1.5 for the runoff time series data for the watershed 5G1C5. Similarly, the kurtosis coefficient was found as 0.2 for the rainfall time series data 2.0 for the runoff time series data for the watershed 5G1C5. The coefficient of variation in time series data of rainfall was found as 52.4 while that of for the time series of runoff was found as 97.7 for the watershed 5G1C5. The coefficient of variation in runoff was found higher as compare to that of rainfall indicating that runoff is influenced by uncertainty in rainfall magnitude as well as its temporal distribution during the monsoon period. The data of rainfall and runoff presented in Table 2 and 3 also supports the same. The rainfall and runoff data showed that the highest rainfall and runoff are not occurred in the same year.

The mean of rainfall depth was found as 801.8 $\mathrm{mm}$ while the median of the rainfall was found as $721.7 \mathrm{~mm}$ for the watershed 5G1C5. The closeness in mean and median values with skewness coefficient of 0.9 indicated that the monsoon rainfall time series is nearly normally distributed. It was found that mean of the runoff depth as $252.1 \mathrm{~mm}$ and the median as $164.8 \mathrm{~mm}$ for the watershed 5G1C5. The difference between mean and median and the value of skewness coefficient (1.5) indicated that the runoff data series are not normally distributed.

The Mann-Kendall statistics showed that the rainfall is increasing significant at 5\% level for the watershed 5G1C5. The slope of the best fit trend line of rainfall was observed as $9.27 \mathrm{~mm}$ per year while that of estimated by Sen's method was found as $15.64 \mathrm{~mm}$ per year. The close agreement was not found between the slopes of the best fit trend line and estimated by Sen's method. It seems that there can be increasing trend in rainfall of watersheds 5G1C5. In fact, the Sen's slope was found insignificant for watershed.
The Mann-Kendall statistics for the runoff data series showed that runoff is increasing significantly at $10 \%$ level in watershed. The result is also supported by the slope of best fitted line $(3.38 \mathrm{~mm} /$ year $)$ and Sen's slope $(5.77 \mathrm{~mm} /$ year $)$ method. There may be significant increasing trend in runoff from watershed.

\section{Ozat river basin}

The time series of seasonal depth of rainfall and runoff for the entire Ozat basin was computed using area weighted value of rainfall and runoff respectively from each watershed of basin. The highest monsoon rainfall depth of $1801.1 \mathrm{~mm}$ and runoff depth of $1114.8 \mathrm{~mm}$ were observed for the Ozat basin. Similarly, the lowest rainfall of 212.6 $\mathrm{mm}$ and runoff depth of $16.4 \mathrm{~mm}$ were found.

The mean of rainfall depth was found as 730.8 $\mathrm{mm}$ while the median of the runoff was found as $674.4 \mathrm{~mm}$ respectively for the basin. The mean of the runoff depth was found as 229.9 $\mathrm{mm}$ and the median as $187.6 \mathrm{~mm}$ for the basin. The difference between mean and median and the value of skewness coefficient indicated that the runoff data series are not normally distributed.

The coefficient of skewness was found as 1.1 for the rainfall time series data and 2.5 for the runoff time series data respectively for the Ozat basin. Similarly, the kurtosis coefficient was found as 1.6 for the rainfall time series data and 8.3 for the runoff time series data for the basin. The coefficient of variation in time series data of rainfall was found as $48.9 \%$ while that of for the time series of runoff was found as $95.7 \%$.

The coefficient of variation in runoff was found higher as compare to that of rainfall reflecting that runoff is influenced by uncertainty in rainfall magnitude as well as its temporal distribution during the monsoon 
period. The data of rainfall and runoff are presented in Table 1 and 2.

The Mann-Kendall statistics showed that the rainfall is increasing non-significantly in the Ozat basin. The slope of the best fit trend line of rainfall was observed as $2.28 \mathrm{~mm}$ per year while that of estimated by Sen's method was found as $7.20 \mathrm{~mm}$ per year for entire basin. The close agreement was found between the slopes of the best fit trend line and estimated by Sen's method.

The Mann-Kendall statistics for the runoff data series showed that runoff is increasing non-significantly. The slope of the best fit trend line of rainfall was observed as -1.37 $\mathrm{mm}$ per year while that of estimated by Sen's method was found as $2.90 \mathrm{~mm}$ per year for entire basin. The Sen's slope was observed as $2.90 \mathrm{~mm}$ per year for the Ozat basin which was insignificant. The conflicting results showed that there cannot change in the runoff from the basin.

\section{Trend analysis of Monsoon Runoff by SWAT}

Arc SWAT 2012 model was used during the study for Ozat river basin. The satellite data for area of interest (Ozat rives basin) were collected from BISAG, Gandhinagar. The input data was in the form of raster dataset. The dataset used namely 90m SRTM DEM (Geotiff), Land use / Land Cover (raster data set) map and soil map (raster data set). These three are imagery data and others input data. Weather data was collected from State Water Data Center (SWDC), Gandhinagar.

The collected data was in the form of excel file. As an input file SWAT required text file for each and every weather. The weather parameters used for SWAT are rainfall (.txt), sun-shine hours (.txt), temperature (max and minimum) (.txt), relative humidity (.txt). By providing single outlet point for entire basin, the basin was distributed in 17 subbasin / HRUs during the analysis. The outlet point (in the form of Latitude / Longitude) is taken from BISAG and verified / checked from Minor Irrigation Department, Junagadh as well as google map window whether the outlet point is correct for basin or not.

During the study, it was seen that highest monsoon runoff depth was $799.5 \mathrm{~mm}$ while the lowest monsoon runoff depth was $0.4 \mathrm{~mm}$. It was found that mean of the runoff depth as $147.3 \mathrm{~mm}$, and the median as $96.7 \mathrm{~mm}$ for the basin. The difference between mean and median and the value of skewness coefficient indicated that the runoff data series are not normally distributed.

The coefficient of skewness was found as 2.4 for the runoff time series data for the watershed and similarly, the kurtosis coefficient was found as 7.6 for the runoff time series respectively.

The coefficient of variation in time series data of runoff was found as 112.6. The coefficient of variation in runoff was found higher as compared to that of rainfall indicating that runoff is influenced by uncertainty in rainfall magnitude as well as its temporal distribution during the monsoon period. The data of rainfall and runoff presented in Table 5 also supports the same.

The Mann-Kendall statistics for the runoff data series showed that runoff is increasing significantly at $5 \%$ level in watershed. The result is also supported by the slope of best fitted line and Sen's slope method. However, the slope of the best fit trend line of runoff was observed as $1.3 \mathrm{~mm}$ per year while that of estimated by Sen's method was found as 3.7 mm per year. 


\begin{tabular}{|c|c|c|c|c|c|}
\hline \multicolumn{6}{|c|}{ Table.1 Monsoon Rainfall for Different watersheds } \\
\hline Year & 5G1C2 & $5 G 1 C 3$ & 5G1C4 & 5G1C5 & MONSOON RF* \\
\hline 1981 & 694.00 & 873.00 & 565.40 & 492.31 & 658.61 \\
\hline 1982 & 585.25 & 485.63 & 456.00 & 332.50 & 444.96 \\
\hline 1983 & 1261.50 & 2269.83 & 1321.17 & 1890.00 & 1801.06 \\
\hline 1984 & 525.00 & 1135.00 & 883.33 & 648.75 & 824.72 \\
\hline 1985 & 190.50 & 435.93 & 359.33 & 427.63 & 378.70 \\
\hline 1986 & 456.50 & 1073.33 & 847.83 & 659.25 & 791.06 \\
\hline 1987 & 28.00 & 302.00 & 226.67 & 211.25 & 212.57 \\
\hline 1988 & 1171.25 & 1417.67 & 1470.67 & 1496.50 & 1413.57 \\
\hline 1989 & 692.25 & 804.00 & 809.83 & 722.23 & 759.22 \\
\hline 1990 & 586.75 & 525.00 & 581.67 & 477.88 & 529.76 \\
\hline 1991 & 320.50 & 418.33 & 469.53 & 611.00 & 476.59 \\
\hline 1992 & 778.75 & 703.33 & 700.67 & 972.38 & 805.75 \\
\hline 1993 & 223.00 & 319.00 & 343.00 & 423.25 & 342.77 \\
\hline 1994 & 1010.50 & 989.33 & 1174.33 & 1548.25 & 1215.12 \\
\hline 1995 & 711.00 & 684.00 & 664.00 & 721.25 & 697.27 \\
\hline 1996 & 428.50 & 578.17 & 585.67 & 786.13 & 624.98 \\
\hline 1997 & 450.75 & 694.17 & 693.83 & 858.75 & 709.55 \\
\hline 1998 & 1050.45 & 634.50 & 737.00 & 917.75 & 817.03 \\
\hline 1999 & 238.50 & 293.50 & 299.67 & 355.38 & 306.44 \\
\hline 2000 & 555.50 & 318.00 & 421.67 & 362.50 & 391.12 \\
\hline 2001 & 704.75 & 647.53 & 744.17 & 503.50 & 626.33 \\
\hline 2002 & 257.00 & 420.33 & 488.00 & 379.13 & 392.19 \\
\hline 2003 & 740.75 & 881.50 & 909.50 & 830.50 & 846.42 \\
\hline 2004 & 876.75 & 704.50 & 817.50 & 827.75 & 795.14 \\
\hline 2005 & 874.00 & 605.50 & 516.83 & 910.00 & 735.62 \\
\hline 2006 & 961.50 & 877.67 & 891.00 & 1119.25 & 975.19 \\
\hline 2007 & 1536.50 & 1262.67 & 1289.33 & 1424.00 & 1366.82 \\
\hline 2008 & 971.00 & 1105.67 & 1209.33 & 1312.28 & 1172.28 \\
\hline 2009 & 1697.00 & 700.83 & 803.80 & 555.50 & 834.42 \\
\hline 2010 & 1459.00 & 1195.33 & 1225.33 & 1276.00 & 1271.29 \\
\hline & & & F: Rainf & & \\
\hline
\end{tabular}




\begin{tabular}{|c|c|c|c|c|c|}
\hline Year & 5G1C2 & 5 G1C3 & 5G1C4 & 5G1C5 & MONSOON RO* \\
\hline 1981 & 112.51 & 201.88 & 125.66 & 116.63 & 144.42 \\
\hline 1982 & 95.11 & 56.00 & 70.35 & 5.47 & 48.07 \\
\hline 1983 & 932.30 & 1477.54 & 856.45 & 1007.00 & 1114.83 \\
\hline 1984 & 69.61 & 462.19 & 325.27 & 87.82 & 246.46 \\
\hline 1985 & 2.54 & 80.61 & 26.55 & 94.00 & 62.31 \\
\hline 1986 & 179.62 & 500.78 & 371.57 & 215.02 & 328.01 \\
\hline 1987 & 0.00 & 42.90 & 34.87 & 6.89 & 22.26 \\
\hline 1988 & 384.04 & 583.93 & 580.62 & 585.37 & 551.01 \\
\hline 1989 & 233.74 & 263.22 & 260.50 & 132.32 & 213.83 \\
\hline 1990 & 193.91 & 127.72 & 141.79 & 87.27 & 127.57 \\
\hline 1991 & 63.79 & 63.52 & 73.90 & 129.74 & 87.77 \\
\hline 1992 & 313.42 & 135.90 & 155.36 & 287.85 & 219.76 \\
\hline 1993 & 0.14 & 31.31 & 53.99 & 42.28 & 34.08 \\
\hline 1994 & 272.21 & 255.25 & 448.46 & 750.24 & 460.36 \\
\hline 1995 & 300.21 & 167.28 & 192.58 & 214.48 & 209.66 \\
\hline 1996 & 149.58 & 161.59 & 180.00 & 278.93 & 202.51 \\
\hline 1997 & 24.30 & 117.77 & 123.22 & 131.13 & 107.94 \\
\hline 1998 & 272.45 & 128.38 & 176.27 & 253.86 & 203.10 \\
\hline 1999 & 1.07 & 11.68 & 10.55 & 31.62 & 16.44 \\
\hline 2000 & 71.01 & 20.61 & 70.79 & 23.64 & 39.18 \\
\hline 2001 & 212.94 & 78.31 & 142.62 & 103.91 & 120.91 \\
\hline 2002 & 24.98 & 96.12 & 103.51 & 111.26 & 90.91 \\
\hline 2003 & 268.70 & 199.68 & 234.84 & 197.25 & 216.69 \\
\hline 2004 & 279.55 & 209.20 & 259.73 & 197.64 & 226.20 \\
\hline 2005 & 360.61 & 231.77 & 194.55 & 419.12 & 309.07 \\
\hline 2006 & 212.15 & 204.59 & 229.40 & 343.81 & 257.27 \\
\hline 2007 & 878.40 & 446.58 & 503.92 & 657.24 & 598.93 \\
\hline 2008 & 250.34 & 413.71 & 482.10 & 614.66 & 467.18 \\
\hline 2009 & 375.44 & 212.90 & 314.58 & 81.78 & 214.25 \\
\hline 2010 & 443.78 & 246.70 & 258.97 & 353.38 & 317.21 \\
\hline \multicolumn{6}{|c|}{ *RO: Runoff } \\
\hline
\end{tabular}


Table.3 Statistical and trend analysis of monsoon rainfall for different watersheds in Ozat River Basin

\begin{tabular}{|c|c|c|c|c|c|c|}
\hline \multirow{2}{*}{\multicolumn{2}{|c|}{ Statistics }} & \multicolumn{4}{|c|}{ Watershed } & \multirow[t]{2}{*}{ Basin } \\
\hline & & $5 \mathrm{G} 1 \mathrm{C} 2$ & $5 \mathrm{G} 1 \mathrm{C} 3$ & $5 \mathrm{G} 1 \mathrm{C} 4$ & $5 \mathrm{G} 1 \mathrm{C} 5$ & \\
\hline \multicolumn{2}{|l|}{$\operatorname{Area}\left(\mathrm{km}^{2}\right)$} & 521.13 & 998.58 & 587.62 & 1068.90 & 3176.24 \\
\hline \multicolumn{2}{|l|}{ Maan Kendal(z) } & $-0.50 \mathrm{NS}$ & $0.36 \mathrm{NS}$ & $1.46^{*}$ & $1.75^{* *}$ & $0.82 \mathrm{NS}$ \\
\hline \multicolumn{2}{|c|}{ Confi. Level in M-K(Z) } & 69.13 & 63.94 & 92.83 & 95.98 & 79.41 \\
\hline \multicolumn{2}{|c|}{ Sen's Slope (mm/year) } & -2.806 & 2.321 & 11.691 & 15.648 & 7.208 \\
\hline \multirow{2}{*}{$\begin{array}{c}\text { Lower and Upper limit of } \\
\text { sens's slope }(1 \%)(\mathrm{mm} / \text { year })\end{array}$} & Lower & -21.69 & -19.53 & -10.4 & -8.48 & -13.53 \\
\hline & Upper & 14.81 & 24.63 & 29.13 & 35.9 & 25.7 \\
\hline \multirow{2}{*}{$\begin{array}{l}\text { Lower and Upper limit of } \\
\text { sens's slope }(5 \%)(\mathrm{mm} / \text { year })\end{array}$} & Lower & -17.54 & -12.68 & -4.29 & -2.95 & -7.7 \\
\hline & Upper & 10.81 & 18.73 & 24.38 & 31.87 & 21.04 \\
\hline \multicolumn{2}{|l|}{ Slope of best fit trend } & -6.31 & -4.15 & 8.1 & 9.27 & 2.28 \\
\hline \multicolumn{2}{|l|}{$\mathrm{R}^{2}(\mathrm{~mm} /$ year $)$} & 0.04 & 0.01 & 0.05 & 0.04 & 0 \\
\hline \multicolumn{2}{|l|}{$\operatorname{Mean}(\mathrm{mm})$} & 472 & 778.5 & 750.2 & 801.8 & 730.8 \\
\hline \multicolumn{2}{|l|}{$\operatorname{Median}(\mathrm{mm})$} & 446.3 & 697.5 & 718.8 & 721.7 & 674.4 \\
\hline \multicolumn{2}{|l|}{ Kurtosis } & 1.1 & 4.5 & -0.5 & 0.2 & 1.6 \\
\hline \multicolumn{2}{|l|}{ Skewness } & 0.9 & 1.7 & 0.5 & 0.9 & 1.1 \\
\hline \multicolumn{2}{|l|}{ Min.(mm) } & 28.0 & 293.5 & 226.7 & 211.3 & 212.6 \\
\hline \multicolumn{2}{|l|}{ Max.(mm) } & 1261.5 & 2269.8 & 1470.7 & 1890 & 1801.1 \\
\hline \multicolumn{2}{|l|}{$\mathrm{CV}(\%)$} & 62.0 & 53.3 & 43.8 & 52.4 & 48.9 \\
\hline
\end{tabular}

Table.4 Statistical and trend analysis of monsoon runoff estimated by SCS curve number method for different watersheds in Ozat River Basin

\begin{tabular}{|c|c|c|c|c|c|c|}
\hline \multirow{2}{*}{\multicolumn{2}{|c|}{ Statics }} & \multicolumn{4}{|c|}{ Watershed } & \multirow[t]{2}{*}{ Basin } \\
\hline & & $5 \mathrm{G} 1 \mathrm{C} 2$ & $5 \mathrm{G} 1 \mathrm{C} 3$ & $5 \mathrm{G} 1 \mathrm{C} 4$ & $5 \mathrm{G} 1 \mathrm{C} 5$ & \\
\hline \multicolumn{2}{|l|}{$\operatorname{Area}\left(\mathrm{km}^{2}\right)$} & 521.13 & 998.58 & 587.62 & 1068.9 & 3176.24 \\
\hline \multicolumn{2}{|l|}{ Maan Kendal(z) } & $0.61 \mathrm{NS}$ & $0.39 \mathrm{NS}$ & $1.18 \mathrm{NS}$ & $1.50 *$ & $0.86 \mathrm{NS}$ \\
\hline \multicolumn{2}{|l|}{ Confi. Level in M-K(Z) } & 72.79 & 65.27 & 88.05 & 93.3 & 80.41 \\
\hline \multicolumn{2}{|l|}{ Sen's Slope (mm/year) } & 1.156 & 1.636 & 4.527 & 5.765 & 2.9 \\
\hline \multirow{2}{*}{$\begin{array}{l}\text { Lower and Upper limit of } \\
\text { sens's slope }(1 \%)(\mathrm{mm} / \text { year })\end{array}$} & Lower & -5.67 & -10.44 & -7.11 & -4.18 & -5.79 \\
\hline & Upper & 8.2 & 8.54 & 11.64 & 17.54 & 10.73 \\
\hline \multirow{2}{*}{$\begin{array}{l}\text { Lower and Upper limit of } \\
\text { sens's slope }(5 \%)(\mathrm{mm} / \text { year })\end{array}$} & Lower & -3.93 & -5.13 & -3.7 & -1.46 & -3.14 \\
\hline & Upper & 5.87 & 7.51 & 9.33 & 13.59 & 8.894 \\
\hline \multicolumn{2}{|l|}{ Slope of best fit trend } & -2.5 & -6.84 & 0.29 & 3.38 & -1.37 \\
\hline \multicolumn{2}{|l|}{$\mathrm{R}^{2}(\mathrm{~mm} /$ year $)$} & 0.01 & 0.05 & 0 & 0.01 & 0 \\
\hline \multicolumn{2}{|l|}{$\operatorname{Mean}(\mathrm{mm})$} & 159.3 & 241 & 233.4 & 252.1 & 229.9 \\
\hline \multicolumn{2}{|l|}{$\operatorname{Median}(\mathrm{mm})$} & 129.8 & 183.5 & 186.3 & 164.8 & 187.64 \\
\hline \multicolumn{2}{|l|}{ Kurtosis } & 11 & 13.7 & 2.8 & 2 & 8.32 \\
\hline \multicolumn{2}{|l|}{ Skewness } & 2.9 & 3.3 & 1.5 & 1.5 & 2.48 \\
\hline \multicolumn{2}{|l|}{ Min.(mm) } & 0 & 11.7 & 10.5 & 5.5 & 16.3 \\
\hline \multicolumn{2}{|l|}{ Max.(mm) } & 932.3 & 1477.5 & 856.5 & 1007 & 1114.8 \\
\hline \multicolumn{2}{|l|}{$\mathrm{CV}(\%)$} & 114.3 & 115 & 81.2 & 97.7 & 95.7 \\
\hline \multicolumn{4}{|c|}{ * Significant at $10 \%$, NS $=$ Non Significant } & & & \\
\hline
\end{tabular}




\begin{tabular}{|c|c|c|c|c|c|}
\hline \multicolumn{7}{|c|}{ Table.5 Rainfall runoff data used for SWAT } \\
\hline Year & $\begin{array}{c}\text { Monsoon } \\
\text { Precipitation } \\
(\mathbf{m m})\end{array}$ & $\begin{array}{c}\text { Monsoon Runoff } \\
(\mathbf{m m})\end{array}$ & Year & $\begin{array}{c}\text { Monsoon } \\
\text { Precipitation } \\
(\mathbf{m m})\end{array}$ & $\begin{array}{c}\text { Monsoon Runoff } \\
(\mathbf{m m})\end{array}$ \\
\hline 1981 & 595.17 & 109.8 & 1996 & 491.03 & 84.62 \\
\hline 1982 & 434.21 & 55.64 & 1997 & 464.5 & 26.52 \\
\hline 1983 & 1186.75 & 799.54 & 1998 & 620.89 & 110.54 \\
\hline 1984 & 530.56 & 86.72 & 1999 & 281.29 & 7.2 \\
\hline 1985 & 303.82 & 9.39 & 2000 & 376.41 & 35.31 \\
\hline 1986 & 501.51 & 67.42 & 2001 & 567.47 & 67.11 \\
\hline 1987 & 95.15 & 0.38 & 2002 & 313.06 & 21 \\
\hline 1988 & 1189.64 & 380.01 & 2003 & 696.26 & 184.6 \\
\hline 1989 & 654.2 & 102.02 & 2004 & 558.87 & 124.7 \\
\hline 1990 & 504.63 & 71.53 & 2005 & 653.23 & 159.06 \\
\hline 1991 & 414.68 & 25.36 & 2006 & 868.3 & 216.25 \\
\hline 1992 & 760.14 & 164.68 & 2007 & 1144.79 & 444.12 \\
\hline 1993 & 288.32 & 8.58 & 2008 & 868.34 & 283.92 \\
\hline 1994 & 889.41 & 255.18 & 2009 & 667.43 & 169.06 \\
\hline 1995 & 568.7 & 91.42 & 2010 & 1063 & 256.79 \\
\hline
\end{tabular}

Table.6 Statistical and trend analysis of monsoon Rainfall and runoff for Ozat River Basin by SWAT Model

\begin{tabular}{|c|c|c|c|}
\hline \multirow{2}{*}{\multicolumn{2}{|c|}{ Statistics }} & \multicolumn{2}{|c|}{ SWAT parameter } \\
\hline & & Precipitation(mm) & Runoff(mm) \\
\hline \multicolumn{2}{|l|}{ Maan Kendal(z) } & $1.5^{*}$ & $1.7 * *$ \\
\hline \multicolumn{2}{|l|}{ Confi. Level in M-K(Z) } & 93.3 & 96.0 \\
\hline \multicolumn{2}{|l|}{ Sen's Slope (mm/year) } & 8.8 & 3.7 \\
\hline \multirow{2}{*}{$\begin{array}{l}\text { Lower and Upper limit of sens's } \\
\text { slope }(1 \%)(\mathrm{mm} / \text { year })\end{array}$} & Lower & -6.0 & -2.8 \\
\hline & Upper & 25.4 & 10.1 \\
\hline \multirow{2}{*}{$\begin{array}{l}\text { Lower and Upper limit of } \\
\text { sens's slope }(5 \%)(\mathrm{mm} / \text { year })\end{array}$} & Lower & -2.0 & -0.4 \\
\hline & Upper & 21.3 & 8.5 \\
\hline \multicolumn{2}{|l|}{ Slope of best fit trend } & 7.6 & 1.3 \\
\hline \multicolumn{2}{|l|}{$\mathrm{R} 2$ (mm/year) } & 0.1 & 0 \\
\hline \multicolumn{2}{|l|}{ Mean $(\mathrm{mm})$} & 618.4 & 147.3 \\
\hline \multicolumn{2}{|l|}{ Median (mm) } & 568.1 & 96.7 \\
\hline \multicolumn{2}{|l|}{ Kurtosis } & -0.1 & 7.6 \\
\hline \multicolumn{2}{|l|}{ Skewness } & 0.6 & 2.4 \\
\hline \multicolumn{2}{|l|}{ Min. (mm) } & 95.2 & 0.4 \\
\hline \multicolumn{2}{|l|}{ Max. (mm) } & 1189.6 & 799.5 \\
\hline \multicolumn{2}{|l|}{$\mathrm{CV}(\%)$} & 45.1 & 112.6 \\
\hline
\end{tabular}




\begin{tabular}{|c|c|c|c|c|}
\hline \multicolumn{5}{|c|}{ Table.7 Trend statics for SWAT results } \\
\hline \multicolumn{2}{|l|}{ Statics } & $\begin{array}{c}\text { Monsoon } \\
\text { seasonal crop } \\
\text { evapotranspiration } \\
(\mathrm{ET})(\mathrm{mm})\end{array}$ & $\begin{array}{l}\text { Monsoon seasonal } \\
\text { potential } \\
\text { evapotranspiration } \\
(\text { PET })(\mathrm{mm})\end{array}$ & $\begin{array}{l}\text { Annual potential } \\
\text { evapotranspiration } \\
(\text { PET })(\mathrm{mm})\end{array}$ \\
\hline \multicolumn{2}{|l|}{ Maan Kendal(z) } & $2.0^{* *}$ & $-0.4 \mathrm{NS}$ & $0.3 \mathrm{NS}$ \\
\hline \multicolumn{2}{|l|}{ Confi. Level in $\mathrm{M}-\mathrm{K}(\mathrm{Z})$} & 97.7 & 65.3 & 61.2 \\
\hline \multicolumn{2}{|l|}{ Sen's Slope (mm/year) } & 1.8 & -0.6 & 1.4 \\
\hline \multirow{2}{*}{$\begin{array}{l}\text { Lower and Upper limit of } \\
\text { sens's slope }(1 \%)(\mathrm{mm} / \text { year })\end{array}$} & Lower & -0.2 & -5.1 & -6.9 \\
\hline & Upper & 4.3 & 2.8 & 8.1 \\
\hline \multirow{2}{*}{$\begin{array}{l}\text { Lower and Upper limit of } \\
\text { sens's slope }(5 \%)(\mathrm{mm} / \text { year })\end{array}$} & Lower & 0 & -4.1 & -5 \\
\hline & Upper & 3.6 & 1.8 & 5.8 \\
\hline \multicolumn{2}{|l|}{ Slope of best fit trend } & 1.9 & -1.1 & -8.4 \\
\hline \multicolumn{2}{|l|}{$\mathrm{R} 2(\mathrm{~mm} /$ year) } & 0.2 & 0 & 0 \\
\hline \multicolumn{2}{|l|}{$\operatorname{Mean}(\mathrm{mm})$} & 183.5 & 673.8 & 2539.9 \\
\hline \multicolumn{2}{|l|}{$\operatorname{Median}(\mathrm{mm})$} & 185.4 & 654.5 & 2600.3 \\
\hline \multicolumn{2}{|l|}{ Kurtosis } & 1.1 & 0.6 & 25 \\
\hline \multicolumn{2}{|l|}{ Skewness } & -0.8 & 0.3 & -4.8 \\
\hline \multicolumn{2}{|l|}{ Min.(mm) } & 60.1 & 507.3 & 613.6 \\
\hline \multicolumn{2}{|l|}{$\operatorname{Max} .(\mathrm{mm})$} & 252 & 855.1 & 2853 \\
\hline \multicolumn{2}{|l|}{$\mathrm{CV}(\%)$} & 22.6 & 10.4 & 14.9 \\
\hline
\end{tabular}

Table.8 Statistical and trend analysis of seasonal groundwater recharge during monsoon by SWAT model for Ozat River Basin

\begin{tabular}{|c|c|c|}
\hline \multicolumn{2}{|l|}{ Statical Parameters } & Monsoon GWR(mm) \\
\hline \multicolumn{2}{|l|}{ Maan Kendal(z) } & $1.9 * *$ \\
\hline \multicolumn{2}{|l|}{ Confi. Level in $\mathrm{M}-\mathrm{K}(\mathrm{Z})$} & 97.3 \\
\hline \multicolumn{2}{|l|}{ Sen's Slope (mm/year) } & 4.4 \\
\hline \multirow{2}{*}{$\begin{array}{l}\text { Lower and Upper limit of sens's } \\
\text { slope }(1 \%)(\mathrm{mm} / \text { year })\end{array}$} & Lower & -1.2 \\
\hline & Upper & 10.3 \\
\hline \multirow{2}{*}{$\begin{array}{l}\text { Lower and Upper limit of sens's } \\
\text { slope }(5 \%)(\mathrm{mm} / \text { year })\end{array}$} & Lower & 0 \\
\hline & Upper & 9.1 \\
\hline \multicolumn{2}{|l|}{ Slope of best fit trend } & 4.5 \\
\hline \multicolumn{2}{|l|}{$\mathrm{R} 2(\mathrm{~mm} /$ year) } & 0.1 \\
\hline \multicolumn{2}{|l|}{$\operatorname{Mean}(\mathrm{mm})$} & 150.1 \\
\hline \multicolumn{2}{|l|}{$\operatorname{Median}(\mathrm{mm})$} & 135.9 \\
\hline \multicolumn{2}{|l|}{ Kurtosis } & 0.3 \\
\hline \multicolumn{2}{|l|}{ Skewness } & 0.9 \\
\hline \multicolumn{2}{|l|}{ Min.(mm) } & 0.7 \\
\hline \multicolumn{2}{|l|}{ Max.(mm) } & 422.3 \\
\hline \multicolumn{2}{|l|}{$\mathrm{CV}(\%)$} & 74.4 \\
\hline \multicolumn{3}{|c|}{$* *$ Significant at $5 \%, *$ Significant at $10 \%$} \\
\hline
\end{tabular}


Table.9 Statistical and trend analysis for the seasonal groundwater recharge by Krishna Rao (1970) during monsoon for different watersheds of the Ozat river basin

\begin{tabular}{|c|c|c|c|c|c|c|}
\hline \multirow{2}{*}{\multicolumn{2}{|c|}{ Statistics }} & \multicolumn{4}{|c|}{ Watershed } & \multirow[t]{2}{*}{ Basin } \\
\hline & & $5 \mathrm{G} 1 \mathrm{C} 2$ & $5 \mathrm{G} 1 \mathrm{C} 3$ & $5 \mathrm{G} 1 \mathrm{C} 4$ & $5 \mathrm{G} 1 \mathrm{C} 5$ & \\
\hline \multicolumn{2}{|l|}{ Maan Kendal(z) } & $-0.97 \mathrm{NS}$ & $0.36 \mathrm{NS}$ & $1.50 *$ & $1.61^{*}$ & $0.81 \mathrm{NS}$ \\
\hline \multicolumn{2}{|l|}{ Confi. Level in M-K(Z) } & 83.4 & 63.96 & 93.33 & 94.63 & 79 \\
\hline \multicolumn{2}{|l|}{ Sen's Slope (mm/year) } & 0 & 0.367 & 2.424 & 3.414 & 1.518 \\
\hline \multirow{2}{*}{$\begin{array}{l}\text { Lower and Upper limit of } \\
\text { sens's slope }(1 \%)(\mathrm{mm} / \text { year })\end{array}$} & Lower & -2.206 & -3.988 & -2.037 & -1.323 & -2.624 \\
\hline & Upper & 0.118 & 5.721 & 6.649 & 8.644 & 5.923 \\
\hline \multirow{2}{*}{$\begin{array}{l}\text { Lower and Upper limit of } \\
\text { sens's slope }(5 \%)(\mathrm{mm} / \text { year })\end{array}$} & Lower & -1.616 & -2.819 & -0.758 & -0.337 & -1.421 \\
\hline & Upper & 0 & 4.224 & 5.643 & 7.468 & 4.699 \\
\hline \multicolumn{2}{|l|}{ Slope of best fit trend } & -1.72 & -1.67 & 1.89 & 2.08 & 0.63 \\
\hline \multicolumn{2}{|l|}{$\mathrm{R}^{2}(\mathrm{~mm} /$ year $)$} & 0.07 & 0.02 & 0.04 & 0.03 & 0 \\
\hline \multicolumn{2}{|l|}{$\operatorname{Mean}(\mathrm{mm})$} & 34.9 & 100.8 & 89.2 & 102.6 & 85.1 \\
\hline \multicolumn{2}{|l|}{$\operatorname{Median}(\mathrm{mm})$} & 9.3 & 74.4 & 79.7 & 80.4 & 67.5 \\
\hline \multicolumn{2}{|l|}{ Kurtosis } & 4.2 & 9.6 & -0.5 & 0.3 & 1.5 \\
\hline \multicolumn{2}{|l|}{ Skewness } & 2.1 & 2.6 & 0.7 & 1 & 1.3 \\
\hline \multicolumn{2}{|l|}{ Min.(mm) } & 0 & 0 & 0 & 0 & 0 \\
\hline \multicolumn{2}{|l|}{ Max.(mm) } & 215.4 & 584.4 & 267.7 & 372.5 & 334.5 \\
\hline \multicolumn{2}{|l|}{$\mathrm{CV}(\%)$} & 160.7 & 115.8 & 88.7 & 99.6 & 98.2 \\
\hline
\end{tabular}

Table.10 Statistical and trend analysis for the seasonal groundwater recharge by Water table fluctuation during monsoon for different watersheds of the Ozat river basin

\begin{tabular}{|c|c|c|c|c|c|c|}
\hline \multirow{2}{*}{\multicolumn{2}{|c|}{ Statistics }} & \multicolumn{4}{|c|}{ Watershed } & \multirow[t]{2}{*}{ Basin } \\
\hline & & $5 \mathrm{G} 1 \mathrm{C} 2$ & $5 \mathrm{G} 1 \mathrm{C} 3$ & $5 \mathrm{G} 1 \mathrm{C} 4$ & $5 \mathrm{G} 1 \mathrm{C} 5$ & \\
\hline \multicolumn{2}{|l|}{ Maan Kendal(z) } & $1.52 *$ & $0.27 \mathrm{NS}$ & $0.08 \mathrm{NS}$ & $0.16 \mathrm{NS}$ & $0.51 \mathrm{NS}$ \\
\hline \multicolumn{2}{|l|}{ Confi. Level in $\mathrm{M}-\mathrm{K}(\mathrm{Z})$} & 93.63 & 60.72 & 53.03 & 56.18 & 69.52 \\
\hline \multicolumn{2}{|l|}{ Sen's Slope (mm/year) } & 0.821 & 0 & 0 & 0 & 0.092 \\
\hline \multirow{2}{*}{$\begin{array}{l}\text { Lower and Upper limit of sens's } \\
\text { slope }(1 \%)(\mathrm{mm} / \text { year })\end{array}$} & Lower & -0.143 & -1.47 & -1.231 & -2.016 & -1.021 \\
\hline & Upper & 2.603 & 1.737 & 1.675 & 3 & 1.862 \\
\hline \multirow{2}{*}{$\begin{array}{l}\text { Lower and Upper limit of sens's } \\
\text { slope }(5 \%)(\mathrm{mm} / \text { year })\end{array}$} & Lower & 0 & -0.909 & -0.891 & -1.25 & -0.546 \\
\hline & Upper & 2.22 & 1.271 & 1.216 & 2.141 & 1.455 \\
\hline \multicolumn{2}{|l|}{ Slope of best fit trend } & 0.98 & 0 & 0.06 & -0.07 & 0.26 \\
\hline \multicolumn{2}{|l|}{$\mathrm{R}^{2}(\mathrm{~mm} /$ year $)$} & 0.05 & 0 & 0 & 0 & 0 \\
\hline \multicolumn{2}{|l|}{$\operatorname{Mean}(\mathrm{mm})$} & 48.64 & 64.54 & 65.19 & 65.02 & 61.26 \\
\hline \multicolumn{2}{|l|}{$\operatorname{Median}(\mathrm{mm})$} & 46 & 55.25 & 60 & 61 & 54.26 \\
\hline \multicolumn{2}{|l|}{ Kurtosis } & 0.45 & 0.19 & 0.53 & 1.5 & 1.13 \\
\hline \multicolumn{2}{|l|}{ Skewness } & 0.96 & 0.46 & 0.43 & 0.89 & 0.76 \\
\hline \multicolumn{2}{|l|}{ Min.(mm) } & 0 & 0 & 0 & 0 & 0 \\
\hline \multicolumn{2}{|l|}{ Max.(mm) } & 201 & 202 & 203 & 224 & 209.42 \\
\hline \multicolumn{2}{|l|}{$\mathrm{CV}(\%)$} & 104.06 & 73.45 & 71.13 & 78.34 & 75.84 \\
\hline
\end{tabular}


Fig.1 Rainfall and runoff relationship in watershed 5G1C2

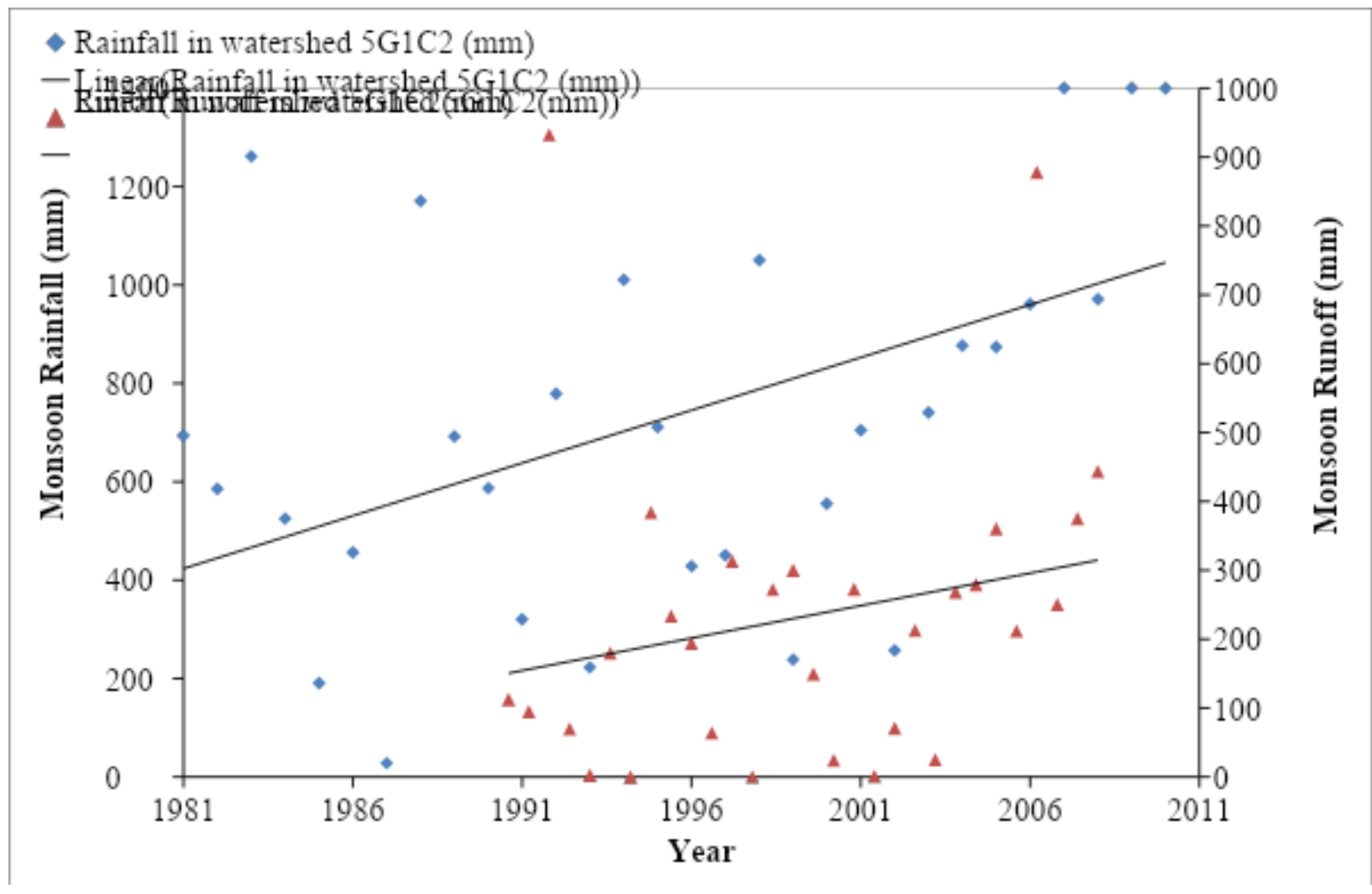

Fig.2 Rainfall and runoff relationship in watershed 5G1C3

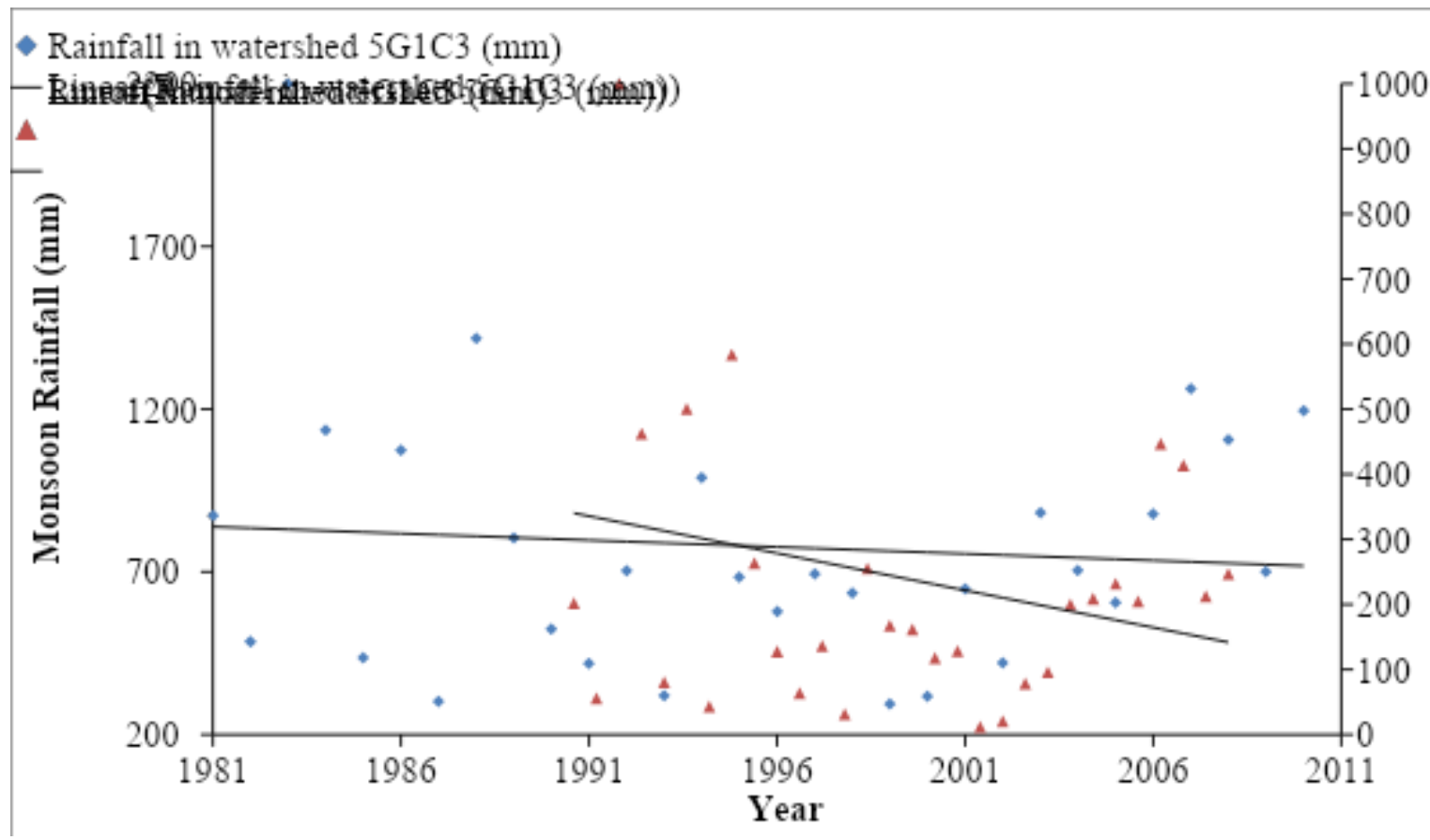

䍙 
Fig.3 Rainfall and runoff relationship in watershed 5G1C4

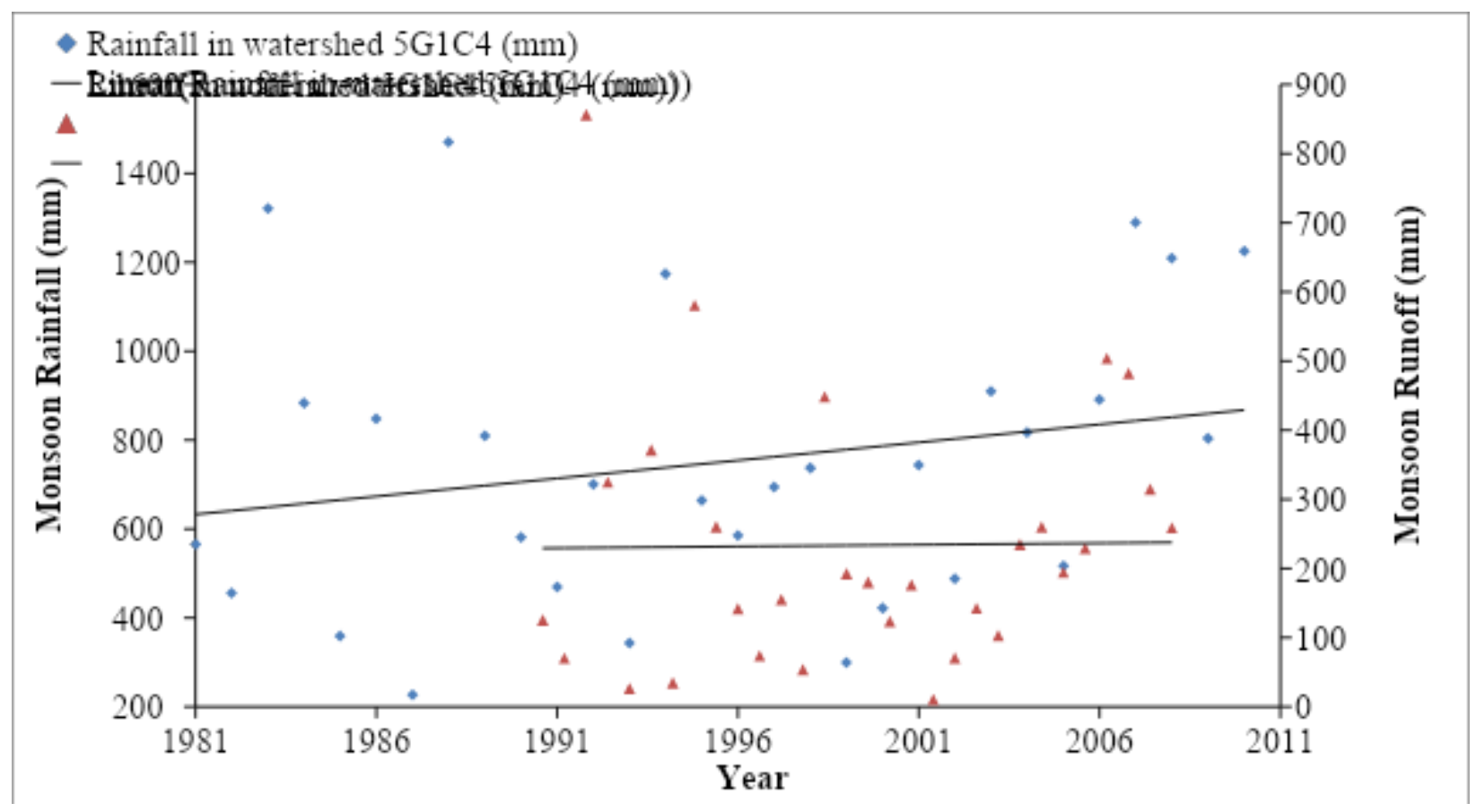

Fig.4 Rainfall and runoff relationship in watershed 5G1C5

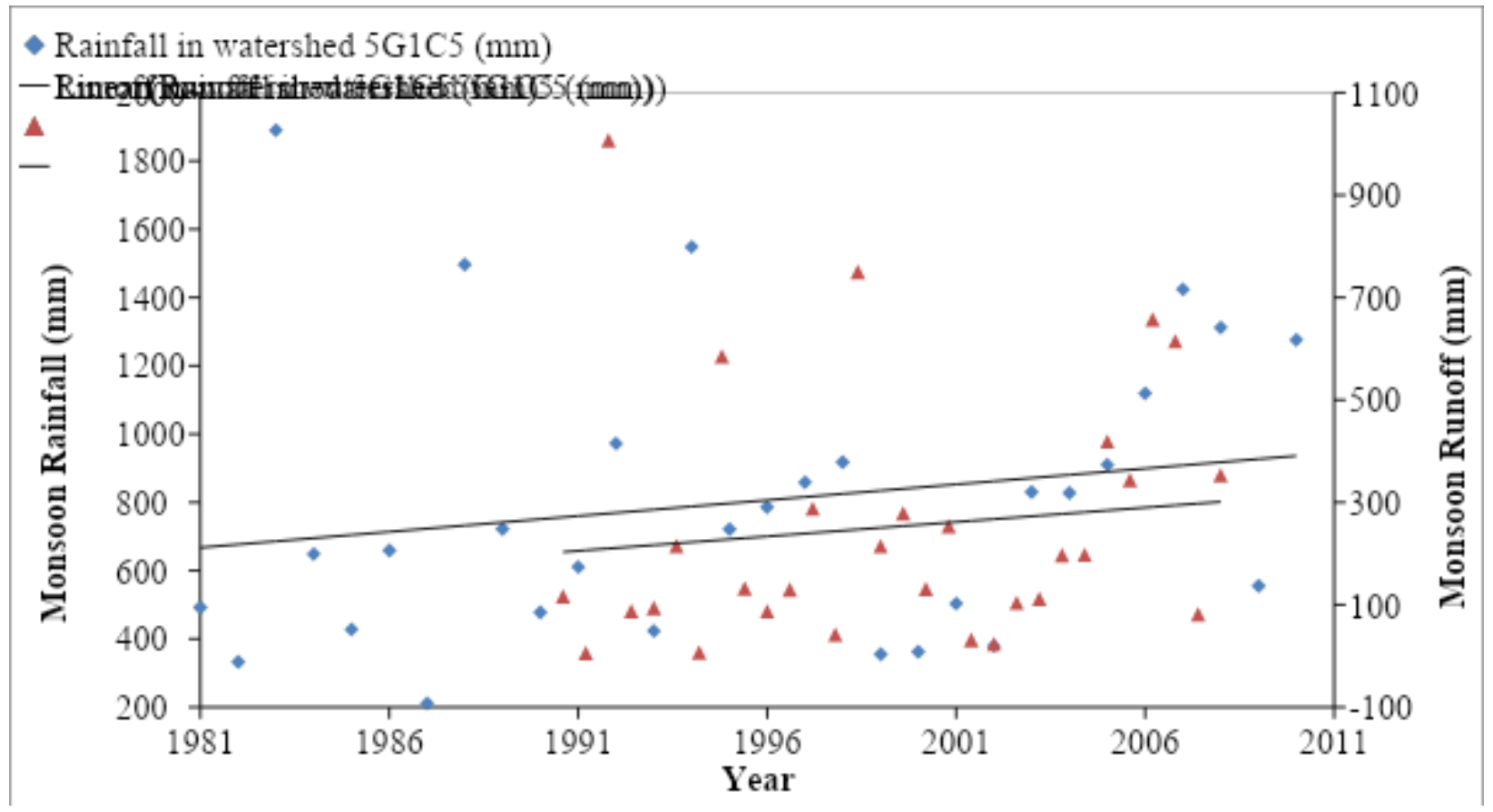


Fig.5 Rainfall and runoff relationship in Ozat river basin

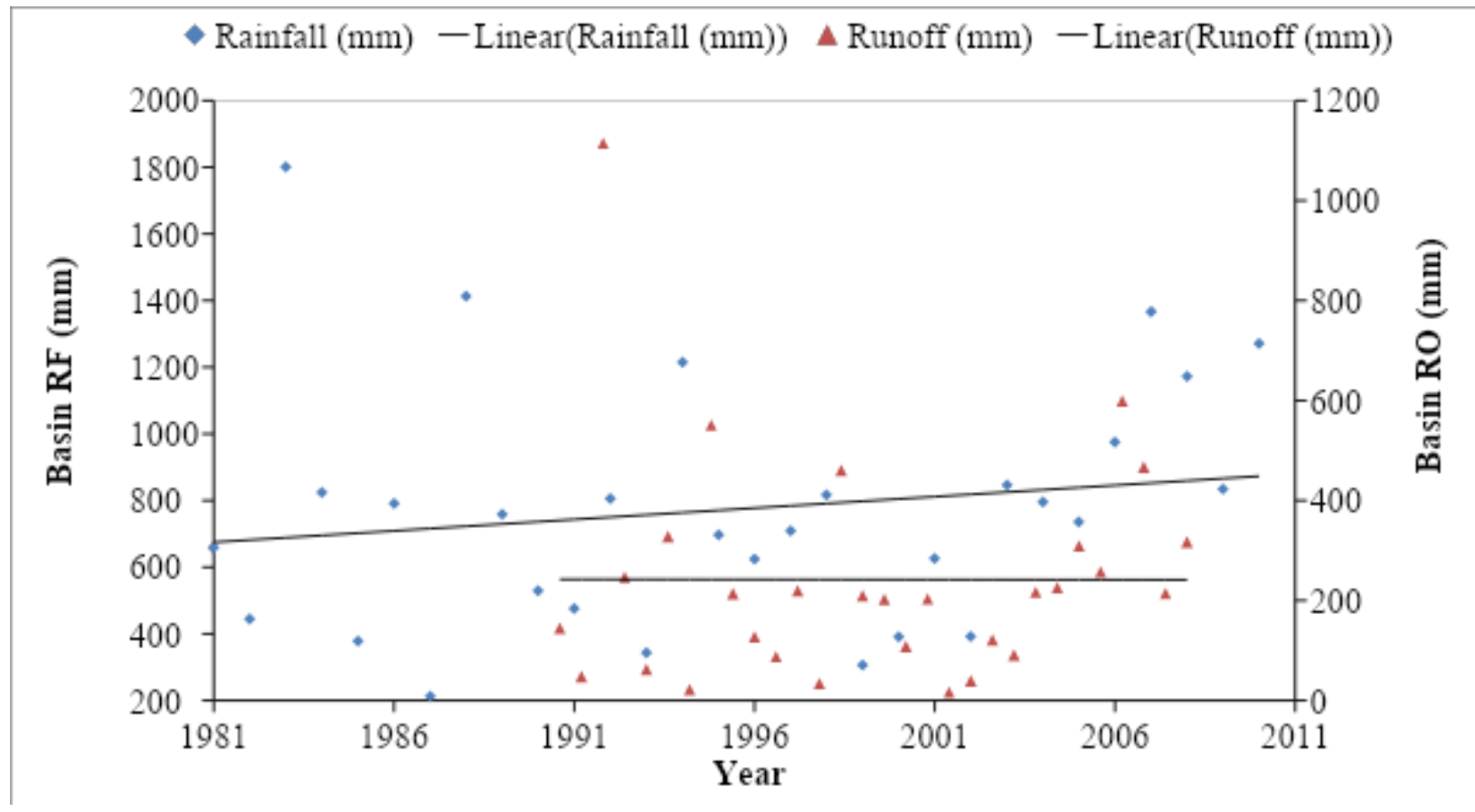

Fig.6 Trend of seasonal potential and crop evapotranspiration during monsoon estimated by SWAT model in Ozat basin

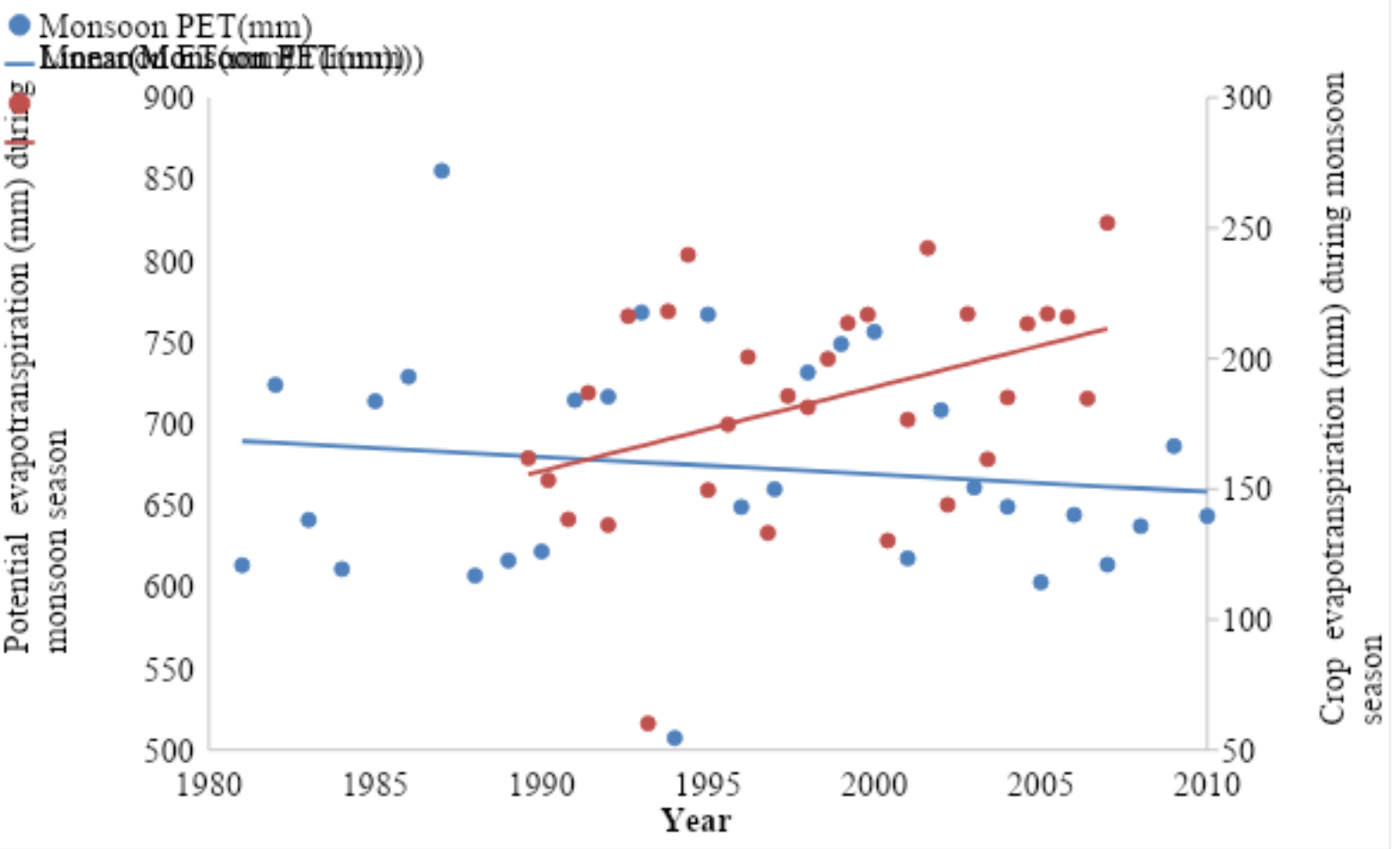


Fig.7 Trend of groundwater recharge by Krishna Rao (1970) approach in 5G1C2 watershed of Ozat river basin

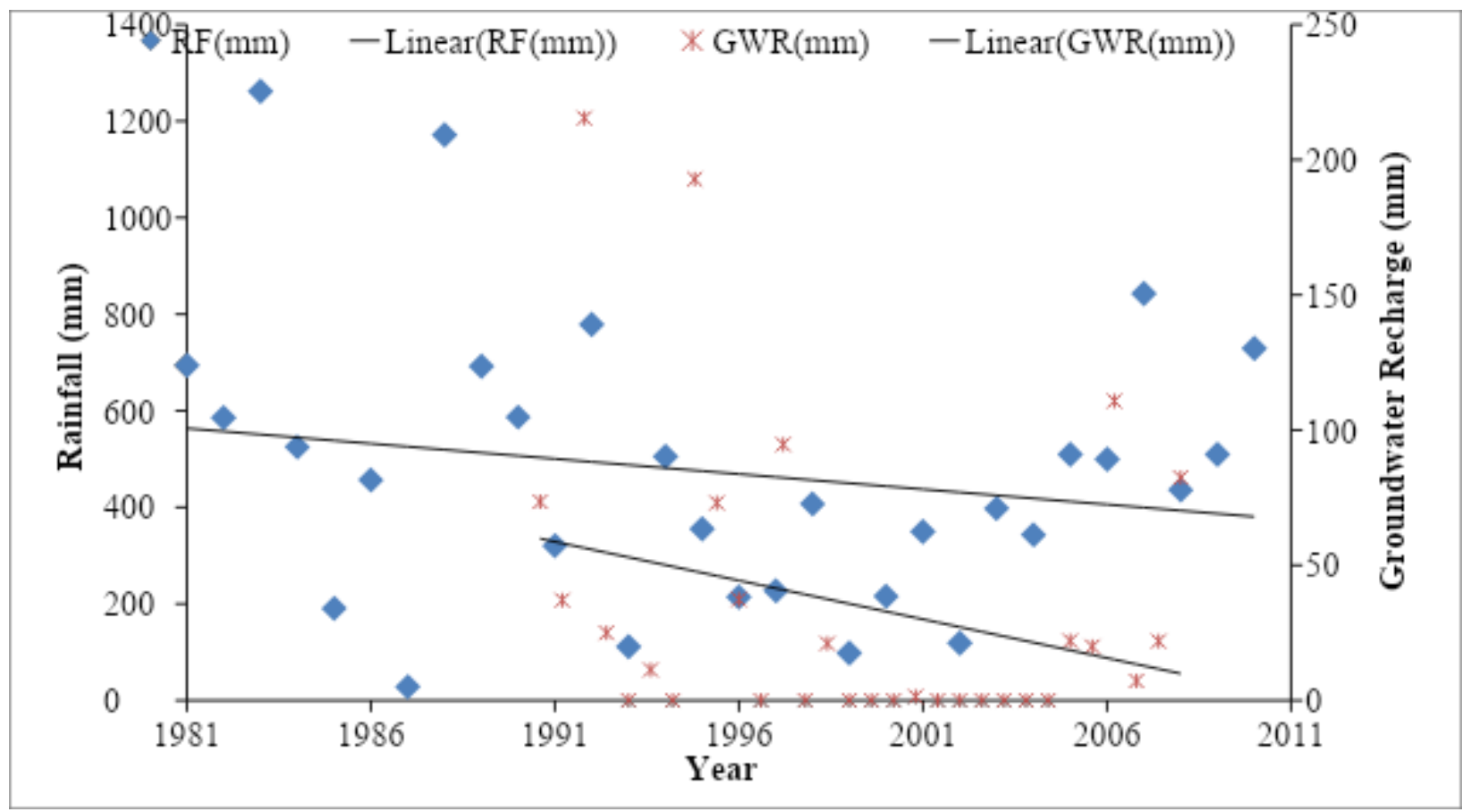

Fig.8 Trend of groundwater recharge by Krishna Rao (1970) approach in 5G1C3 watershed of Ozat river basin

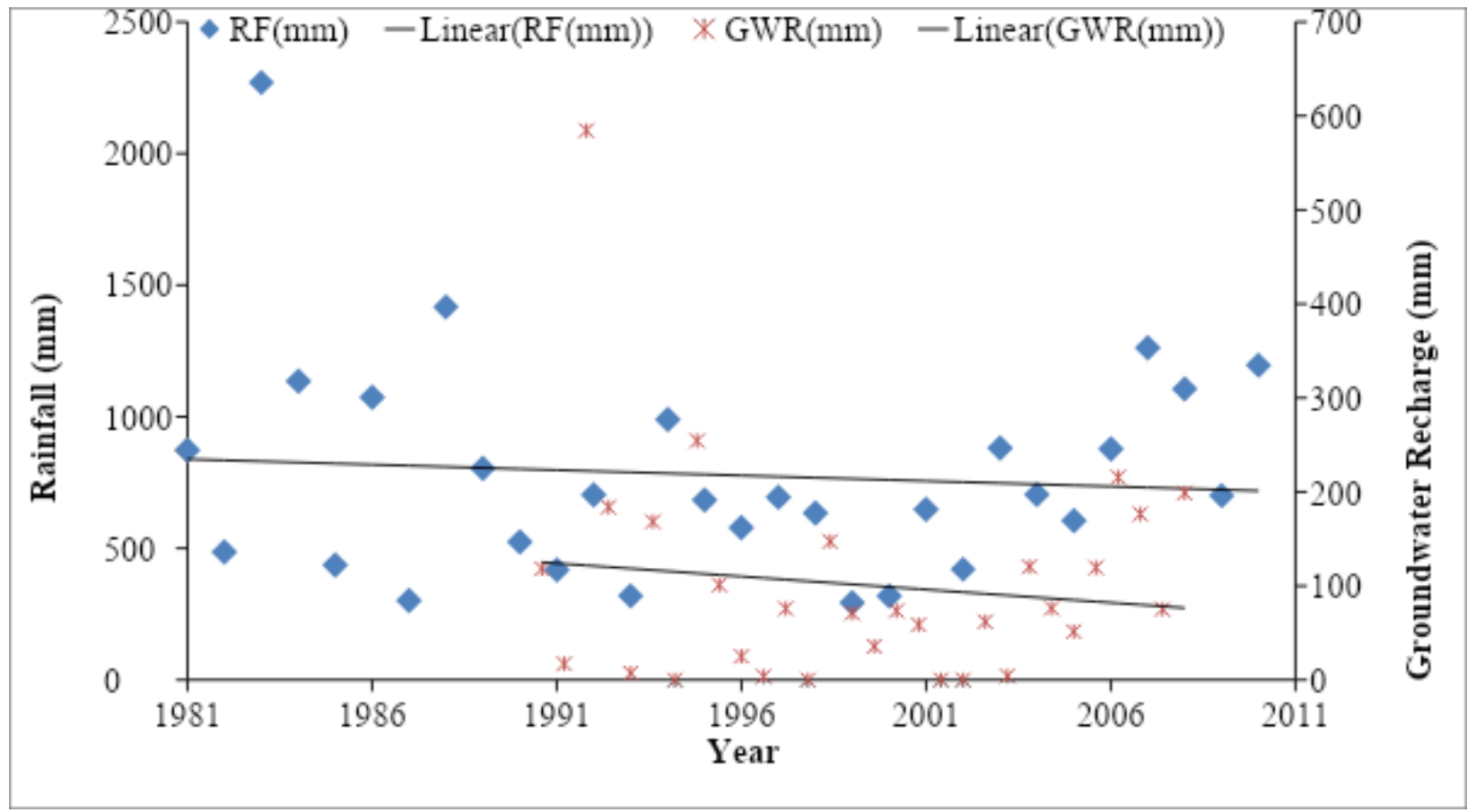


Fig.9 Trend of groundwater recharge by Krishna Rao (1970) approach in 5G1C4 watershed of Ozat river basin

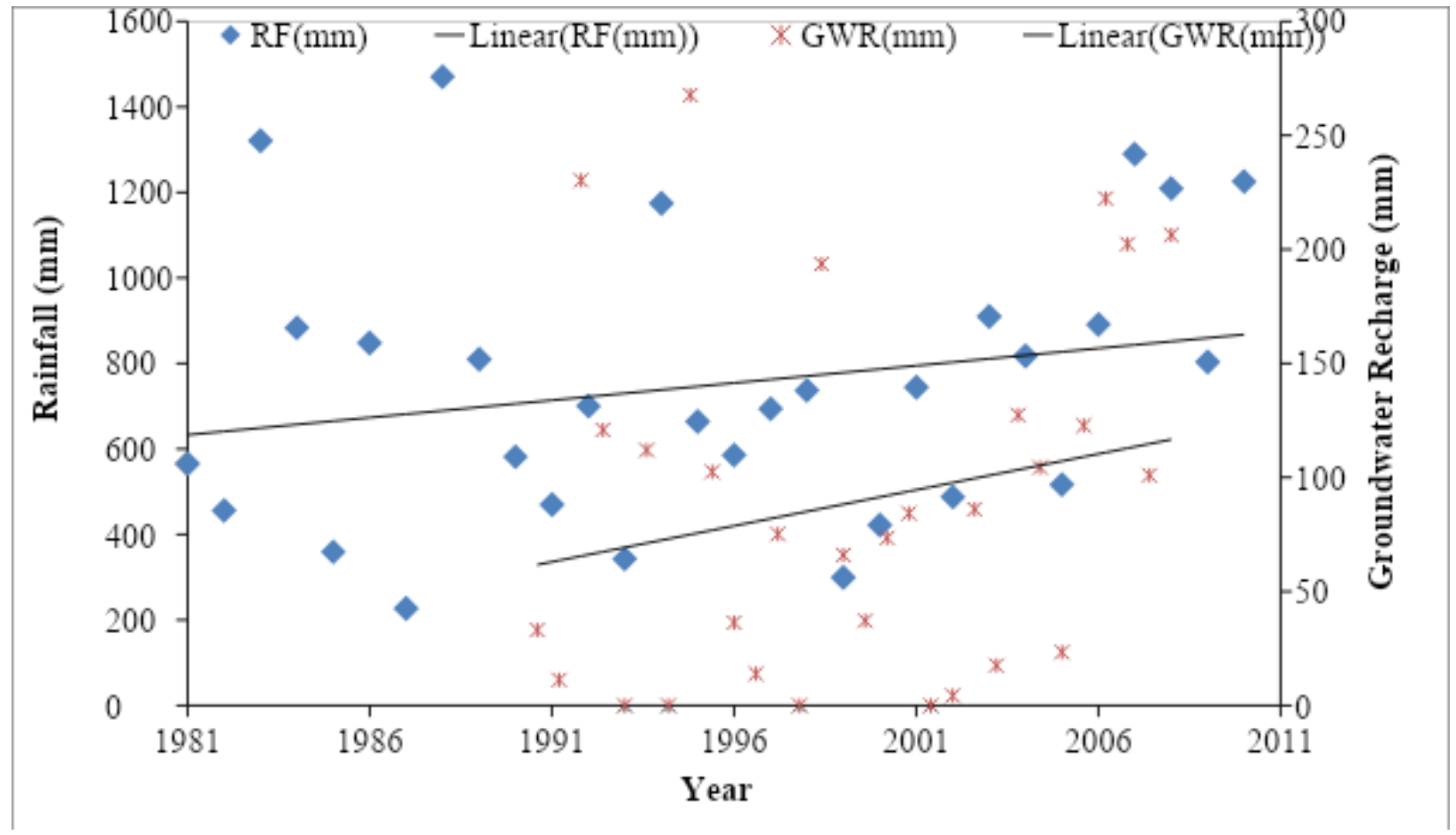

Fig.10 Trend of groundwater recharge by Krishna Rao (1970) approach in 5G1C5 watershed of Ozat river basin

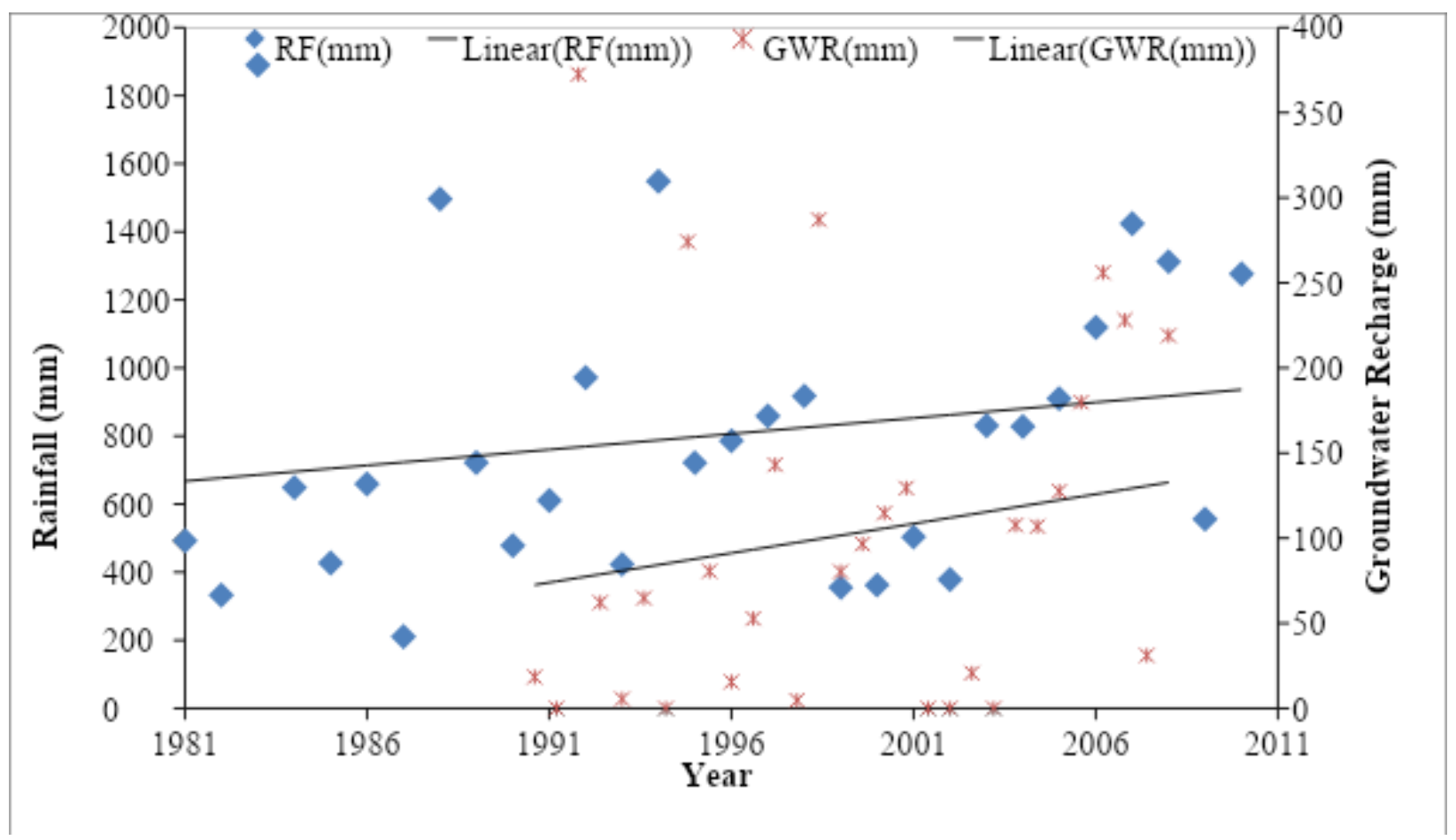


Fig.11 Trend of groundwater recharge by Krishna Rao (1970) approach in Ozat river basin

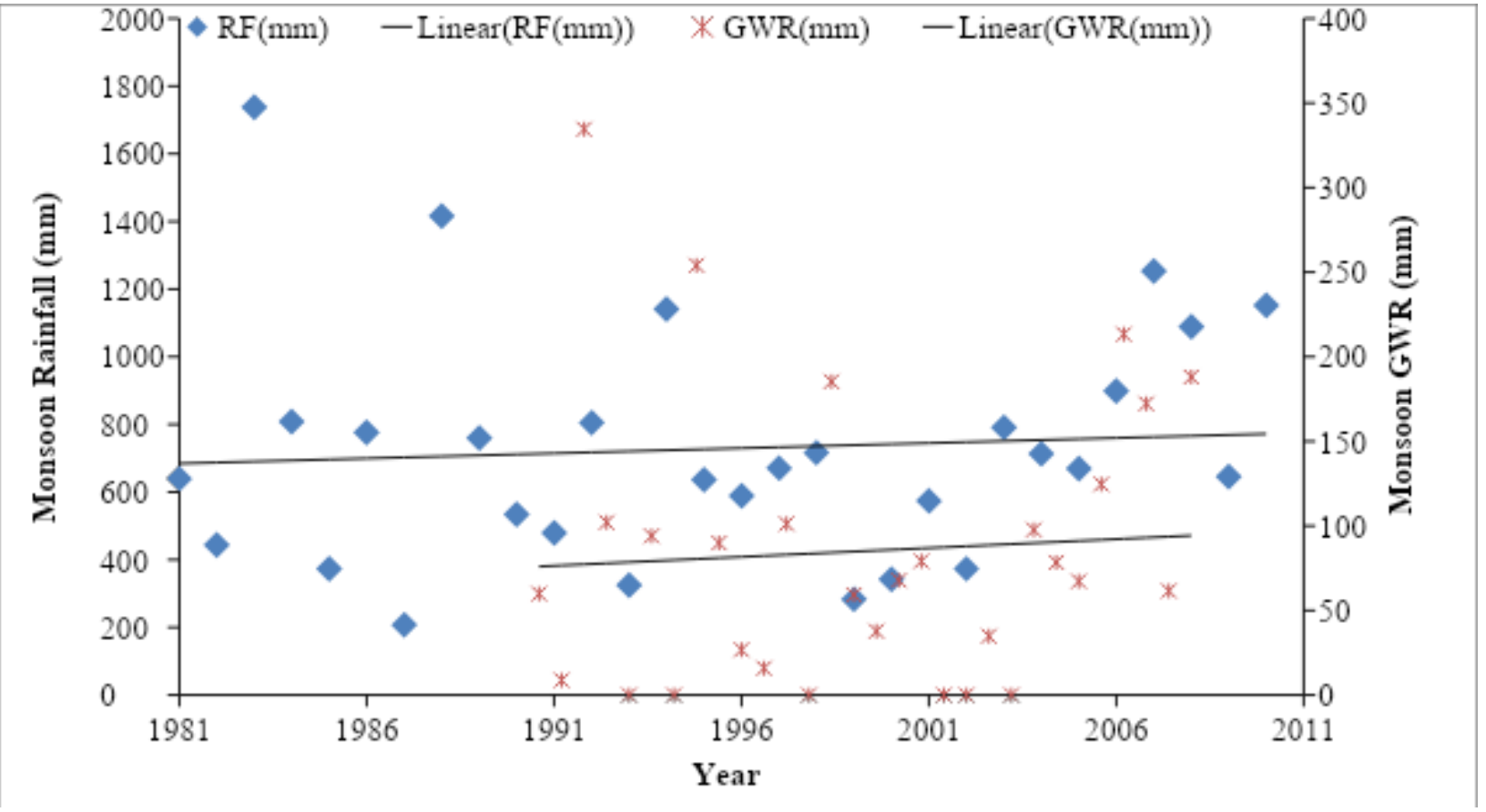

Fig.12 Rainfall variability impact on groundwater recharge estimated by different methods for Ozat river basin

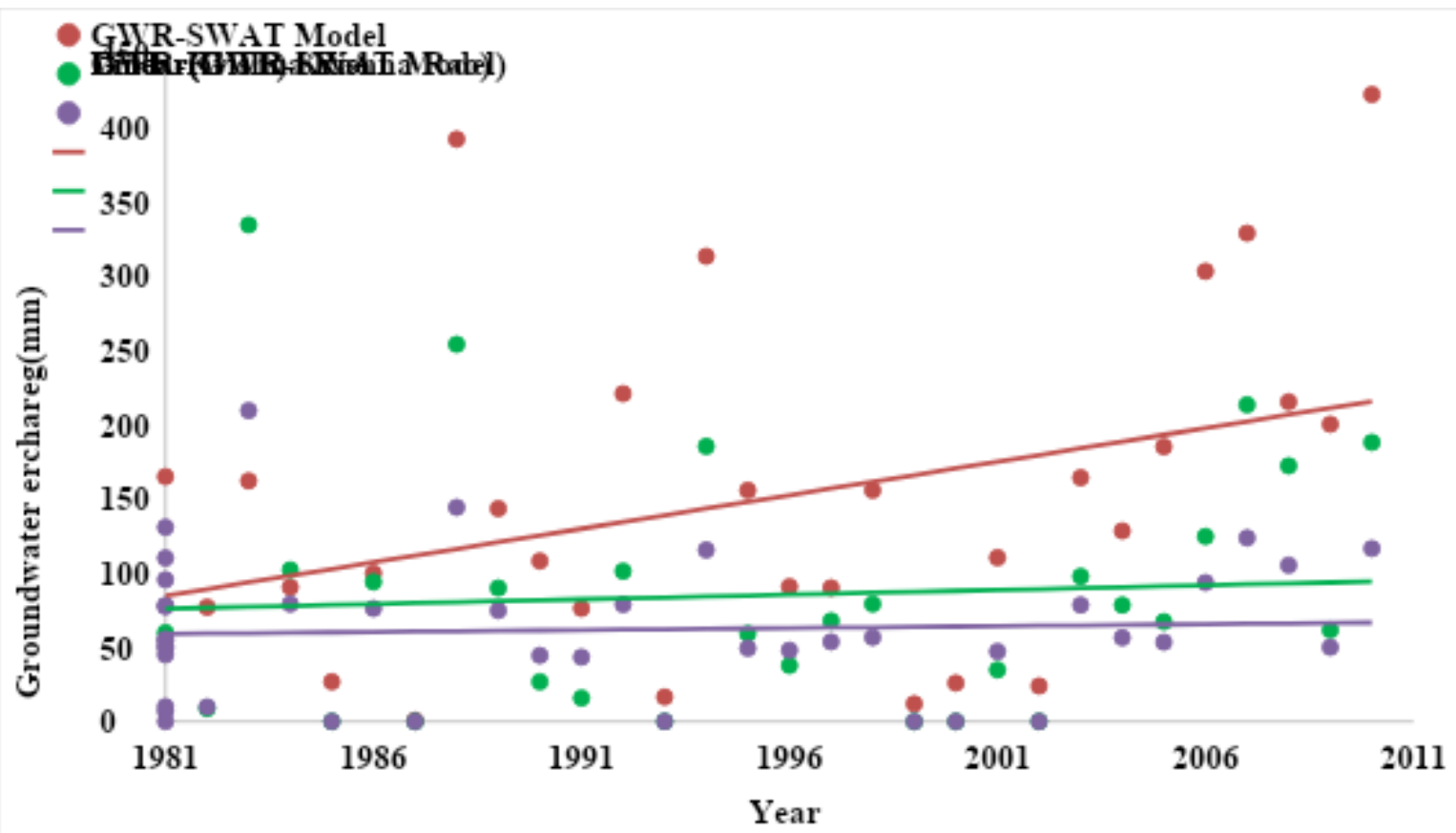


Fig.13 Trend of groundwater recharge by water table fluctuation method in 5G1C2 watershed

Rainfall (mm)

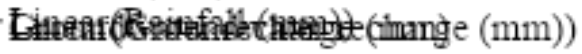

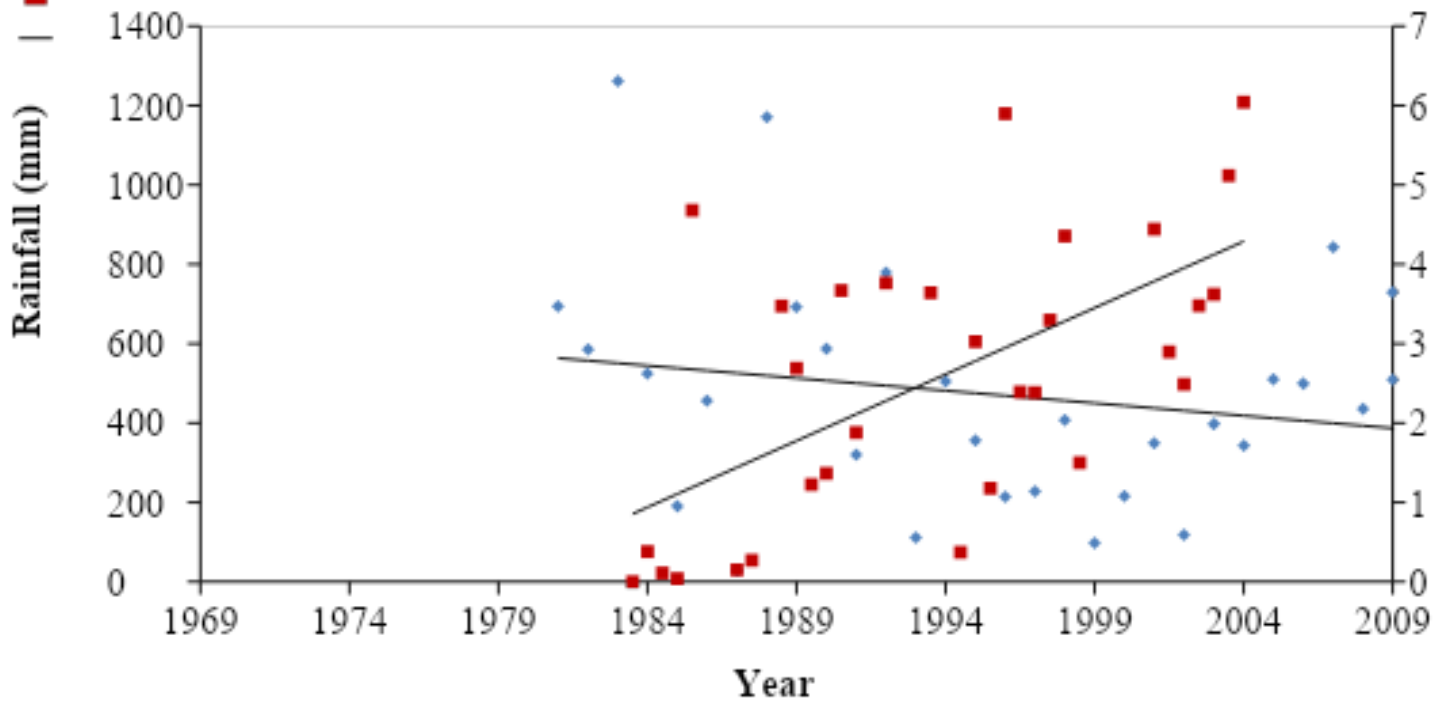

Fig.14 Trend analysis of groundwater recharge by water table fluctuation method in Ozat river basin

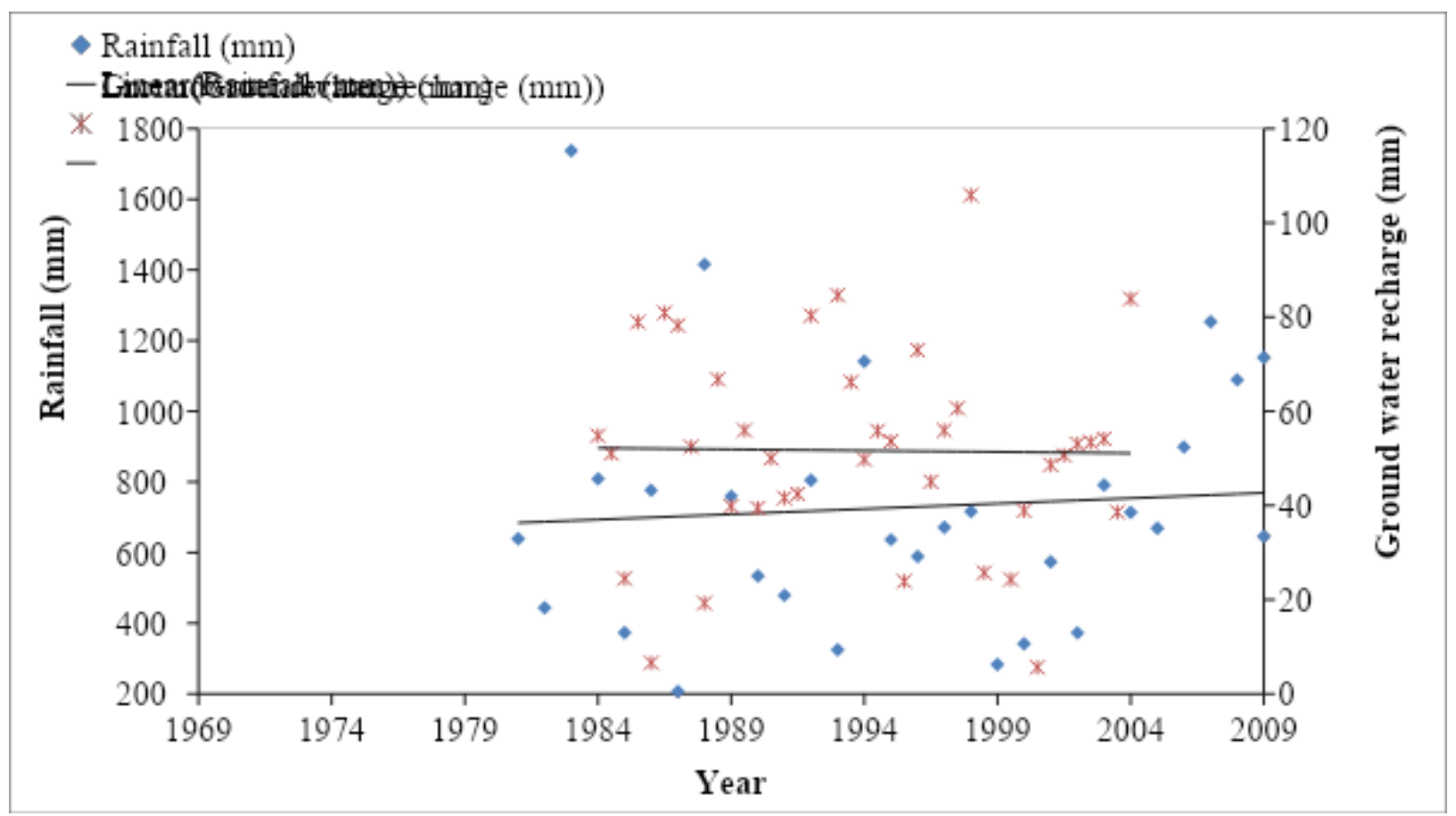


There may be significant increasing trend in runoff from watershed. The coefficient of variation value was found $112.6 \%$ for the Ozat river basin. The statistical data supported same as Table 6.

\section{Evapotranspiration}

The seasonal potential and crop evapotranspiration during monsoon were determined using the SWAT model for the Ozat basin for the year 1981 to 2010 which are shown in Fig. 6. It can be seen in Fig. 6 that the seasonal crop evapotranspiration during monsoon is increasing in the Ozat basin even though the potential evapotranspiration is decreasing. The ManKendall and Sen's slope statistics along with other statistics parameters were found as shown in Table 7. It can be seen in Table 7 that the seasonal potential evapotranspiration (PET) during monsoon is decreasing insignificantly at the rate of $1.1 \mathrm{~mm} /$ year during the monsoon season while the crop evapotranspiration (ET) is increasing significantly at the rate of $1.9 \mathrm{~mm} /$ year. The Sen's slope for the time series (1981-2010) of seasonal crop evapotranspiration (ET) and potential evapotranspiration (PET) were found as $1.8 \mathrm{~mm} /$ year and $-0.6 \mathrm{~mm} /$ year. The results of Man-Kendall and Sens slope statistics are found comparable.

The slope of the best fit trend line of annual PET showed that it is also deceasing at the rate $8.4 \mathrm{~mm} /$ year. The decrease in potential evapotranspiration is due to increase in the relative humidity because of increasing the temperature. This is called evaporation paradox. While potential evapotranspiration rates are known to increase with higher temperature, other factors in addition to rising temperatures also affect evapotranspiration (ET). The increasing humidity and higher $\mathrm{CO}_{2}$ concentrations both tend to reduce transpiration and counteract the higher temperature effects on ET. As the oceans and other water bodies warm and evaporate more water into the atmosphere, global humidity is likely to increase. As $\mathrm{CO}_{2}$ concentrations increase, leaf stomata partially close in response to maintain the $\mathrm{CO}_{2}$ concentration inside the stomata. Thus, while climate change is likely to increase air temperature, the effect of higher humidity and $\mathrm{CO}_{2}$ concentration could partially offset the temperature effect on ET. The results indicate that little or no change in PET is likely due to increasing air temperature. The impact of global warming on PET will likely be less in locations with higher wind speeds (Harmsen, et al., 2007). For the Targhadiya station near to Rajkot, the annual average of temperature is found increasing while relative humidity is decreasing; the trend of both can lead to increase reference evapotranspiration. However, the PET is found decreasing (Anonymous, 2011). The reason is decrease in wind velocity and bright sunshine hours. Similar to PET, the pan evaporation is also found decreasing. It is not expected that evaporation and evapotranspiration would increase with temperature increases (Snyder, et al., 2011). This contradiction is the so called "Pan Evaporation paradox". The pan evaporation paradox was found in the northwest China (Brutsaert and Parlange, 1998). Also it was noted that actual evaporation has a increasing trend over Southern Russia and most of the united states during the past 40 years (Zailin, et al., 2013), supporting the explanation about the Pan evaporation paradox (Snyder, et al., 2011). Many evidences showed that PET decreased over the last decade in the world, such as in India (Golubev, et al., 2001) and China (Liu, et al., 2001; Shenbin, 2006; Chattopadhyay and Hulme, 1997; Brutsaert et al., 1998; Chen, et al., 2005). The same trend of pan evaporation was also found in the USA and across many part of the former Soviet union (Gao, et al., 2006; Zailin, et al., 2013), China (Liu, et al., 2001; Peterson et al., 1995), 
India (Golubev, et al., 2001), Australia and New Zealand (Bandyopadhyay et al., 2009) but a small significant increase in Israel (Chen, et al., 2005)

\section{Groundwater recharge}

The trends of the groundwater estimated by three methods are compared in Fig. 7. It shows that the groundwater recharge is in increasing trend under all the three methods. The Fig. 7 shows that the groundwater recharge estimated by three methods namely SWAT model, Krishna-Rao method and water table fluctuation method for the Ozat basin is in increasing trend. The time series of groundwater recharge data(1980-2010) estimated by SWAT model and Krishna Rao (1970) and time series of groundwater recharge (1969-10) by water table fluctuation method were analyzed for the statistical parameter and trend analysis using MannKendall and Sen's method. The statistical parameter along with Mann-Kendall and Sen's slope statistics were obtained as presented in table 8, 9 and 10 for the SWAT model, Krishna Rao (1970) and water table fluctuation methods.

\section{Groundwater recharge estimated by SWAT model}

The seasonal groundwater recharge during monsoon season was determined for the Ozat basin from 1981 to 2010 using SWAT model. The Man-Kendall and Sen's slope statistics along with other statistical parameters are shown in Table 9. It can be seen that the the groundwater recharge is in increasing significantly $(5 \%)$. The slope of best fitted trend line and Sens slope were found as $4.5 \mathrm{~mm} /$ year and $4.4 \mathrm{~mm} /$ year. The Sen's slope was also found significant $(5 \%)$. That indicated that the seasonal groundwater recharge during monsoon in the Ozat basin will be increased $4.5 \mathrm{~mm} /$ year. The mean groundwater recharge during monsoon season is $150 \mathrm{~mm}$. The minimum and maximum groundwater recharges during the monsoon season were found as $0.7 \mathrm{~mm}$ and $422.3 \mathrm{~mm}$ respectively.

\section{Groundwater recharge by Krishna Rao (1970) Approach}

\section{Watershed 5G1C2 and 5G1C3}

The mean and median of the groundwater recharge time series data was observed as 34.9 and 100.8 , and 9.3 and $74.4 \mathrm{~mm}$, respectively for the watershed $5 \mathrm{G} 1 \mathrm{C} 2$ and $5 \mathrm{G} 1 \mathrm{C} 3$. Similarly, the coefficient of variance was observed as 160.7 and $115.8 \%$ respectively.

The Mann-Kendall statistics showed that the groundwater recharge was insignificantly decreasing and insignificant increasing for watershed $5 \mathrm{G} 1 \mathrm{C} 2$ and $5 \mathrm{G} 1 \mathrm{C} 3$ respectively. The Sen's slope statistics also support the Mann-Kendall statistics. The Sen's slope was found as 0 for watershed $5 \mathrm{G} 1 \mathrm{C} 2$, and 0.367 for watershed 5G1C3 which were insignificant. There was no close agreement between the Sen's slope and the slope of the best fitted trend line (Fig. 7 and 8) respectively for watershed $5 \mathrm{G} 1 \mathrm{C} 2$ and $5 \mathrm{G} 1 \mathrm{C} 3$. However, there may not be significant change in groundwater recharge for the watersheds $5 \mathrm{G} 1 \mathrm{C} 2$ and $\mathrm{C} 3$.

\section{Watershed 5G1C4 and C5}

The mean and median of the groundwater recharge time series data was observed as 89.02 and 102.6 , and $79.7 \mathrm{~mm}$ and $80.4 \mathrm{~mm}$ $\mathrm{mm}$ respectively for the watershed 5G1C3 and C4. Similarly, the coefficient of variance was observed as 88.7 and $99.6 \%$ respectively.

The Mann-Kendall statistics showed that the groundwater recharge was significantly increasing at $10 \%$ level for both watershed 
5G1C4 and 5G1C5. The Sen's slope statistics also support the Mann-Kendall statistics. The Sen's slope was found as 2.424 and 3.414 $\mathrm{mm}$ /year for the both watersheds C4 and C5 respectively. There was no close agreement between the Sen's slope and the slope of the best fitted trend line. Figure 9 and 10 shows that the relationship for watershed 5G1C4 and 5G1C5 respectively. The groundwater recharge may increase at the rate of $18.9 \mathrm{~mm}$ and $20.8 \mathrm{~mm}$ per decade due to increasing trend for the watershed 5G1C4 and 5G1C5 respectively.

\section{Ozat River basin}

The mean and median of the groundwater recharge for the entire river basin was observed as 85.15 and $67.5 \mathrm{~mm}$, respectively. Similarly, the coefficient of variance, skewness and kurtosis was observed as $98.2 \%$, 1.3 and 1.5, respectively. The seasonal groundwater recharge estimated by Krishna Rao method was found as $12 \%$ of the monsoon rainfall for the entire Ozat basin. However, these results were not comparable with Oke et al., (2013) who found the groundwater recharge as $16 \%$ to $18 \%$ of the areal rainfall (average annual rainfall of 1476 $\mathrm{mm}$ ) in Ogun-Oshun river basin in Nigeria using three empirical methods namely modified Chaturvedi formula (1936) and Krishna Rao (1970) in Kumar, (2009); Kumar and Seethapathi (2002). The reason was that the rainfall is low $(715 \mathrm{~mm})$ for the study area. The percentage groundwater recharge can be lower for the lower rainfall amount.

The Mann-Kendall statistics showed that the groundwater recharge was insignificantly increasing for entire basin. Also, the Sen's slope statistics showed that the groundwater recharge is insignificantly increasing for the entire basin. The best fitted trend line (Fig. 11) also showed increasing trend. The groundwater recharge will increase by the tune of $6.3 \mathrm{~mm}$ per decade in the basin. The significant trend was found in time series of groundwater recharge estimated by KrishnaRao method (Fig. 12).

\section{Groundwater recharge by water table fluctuation method}

\section{Watershed 5G1C2 and 5G1C3}

The mean and median of the groundwater recharge time series data was observed as 46.84 and 64.54 , and 46.00 and $55.25 \mathrm{~mm}$ respectively for the watershed $5 \mathrm{G} 1 \mathrm{C} 2$ and 5G1C3. Similarly, the coefficient of variance was observed as 104.06 and $73.45 \%$ respectively.

The Mann-Kendall statistics showed that the groundwater recharge was significantly increasing at $10 \%$ for the watershed $5 \mathrm{G} 1 \mathrm{C} 2$ while insignificantly increasing for watershed 5G1C3. The Sen's slope statistics also support the Mann-Kendall statistics. The Sen's slope was found as 0.821 and 0.00 for watershed $5 \mathrm{G} 1 \mathrm{C} 2$ and $5 \mathrm{G} 1 \mathrm{C} 3$ respectively. There was no close agreement between the Sen's slope and the slope of the best fitted trend line.

\section{Watershed 5G1C4 and C5}

The mean and median of the groundwater recharge time series data was observed as $65.19,65.02$ and 65.02, $61.00 \mathrm{~mm}$ respectively for the watershed 5G1C4 and C5. Similarly, the coefficient of variance was observed as 71.13 and $78.34 \%$ respectively (Fig. 13).

The Mann-Kendall statistics showed that the groundwater recharge was significantly increasing for both watersheds 5G1C4 and 5G1C5. The Sen's slope statistics also support the Mann-Kendall statistics. The Sen's slope was found as 0.00 and 0.09 for the watershed $5 \mathrm{G} 1 \mathrm{C} 4$ and 5G1C5 watershed respectively. 
There was close agreement between the Sen's slope and the slope of the best fitted trend line. Therefore, there may be significant impacts of rainfall variability on groundwater recharge for the watershed 5G1C4 and 5G1C5.

\section{Ozat River basin}

The groundwater recharge for the basin as a whole was computed by the area weightage method using groundwater recharge data of the basin. The mean and median of the groundwater recharge for the entire river basin was observed as 61.26 and $54.26 \mathrm{~mm}$ respectively. Similarly, the coefficient of variance, skewness and kurtosis was observed as $75.84 \%, 0.76$ and 1.13 respectively. The Mann-Kendall statistics showed that the groundwater recharge was non-significantly increasing for the entire basin.

The Sen's slope statistics also showed that the groundwater recharge is increasing insignificantly for the basin. The best fitted trend line (Fig. 14) also showed no trend. So, there may not be much impact of rainfall variability on groundwater recharge estimated by water table fluctuation method. Due to rainfall variability the groundwater recharge will increase by the tune of $2.6 \mathrm{~mm}$ per decade for river basin.

\section{Trend analysis of evapotranspiration}

The seasonal potential evapotranspiration in the Ozat basin was found insignificantly decreasing while crop evapotranspiration significantly increasing indicating that rainfall is increasing due to climatic variability.

\section{Trend analysis of rainfall and runoff}

The average monsoon rainfall of the Ozat basin is found as $730.81 \mathrm{~mm}$. The rainfall and runoff both were found increasing respectively in 1 and 3 watersheds of the basin out of 4 .
However, rainfall is significantly increasing in 2 watersheds (5G1C4, 5G1C5) while runoff is significantly increasing in 1 watershed (5G1C5) only. The rainfall is observed insignificantly decreasing in 1 watershed (5G1C2). The area weighted rainfall and runoff are found increasing in the basin. The rainfall and runoff is found increasing insignificantly for the entire river basin.

\section{Trend analysis of groundwater recharge}

Among 4 watersheds of the basin, the groundwater recharge estimated by Krishna Rao (1970) and water table fluctuation methods is increasing in 2 (5G1C4 and 5G1C5) and 1 (5G1C2) watersheds, respectively. The groundwater recharge estimated for entire Ozat basin during monsoon is found increasing significantly by SWAT model while increasing insignificantly by Krishna Rao (1970) and water table fluctuation methods respectively due to rainfall variability.

\section{References}

Anonymous. 2011). Water balance and assessment of groundwater recharge in Meghal river basin of Saurashtra region, AICRP on groundwater utilization, Junagadh Agricultural University, Junagadh, Gujarat. Published on Feb 2011: 115-139.

Bandyopadhyay, A., Bhadra, A., Raghuwanshi, N.S. and Singh, R. 2009. Temporal trends estimates of reference evapotranspiration over India. Journal of Hydrological Engineering. 14(5): 508-315.

Brutsaert, W. and Paarlange, M.B. 1998. Hydrological cycle explains the evaporation paradox, Nature. 30: 396403. 
Brutsaert. 1998. Effects of Climate Change on Agriculture, Land Resources, Water Resources. By Peter Backlund.

Brutsaert. 1998. Effects of Climate Change on Agriculture, Land Resources, Water Resources. By Peter Backlund.

Chattopadhyay, N. and Hulme, M. 1997. Evaporation and potential evapotranspiration in India under conditions of recent and future climate change. Agricultural and Forest Meteorology. 87: 55-73.

Chen, H.Z., Shi, G.Y., Zhag, X.Y., Arimoto, R., Zhao, J. Q., Xu, L., Wnag, B. and Chen, Z.H. 2005. Analysis of 40 years of solar radiation data from china, 1961-2000. Geophysical. Research. Letter. 32:608-618.

Gao, G., Chen, D., Xu, C. and Simelton, E. 2006. Trend of estimated actual evapotranspiration over China during 1960-2002. Climate and Dynamics. 112(D11): 1-13.

Golubev, V.S., Lawrimore, H.J., Pavel, Ya, Groisman, Speranskaya, N.A., Sergey A. Z., Matthew, J. M., Thomas, C. P. and Robert W. M. 2001. Evaporation changes over the contiguous United States and the former USSR: A reassessment. Geophysical research letters. (28).

Goludev, V.S., Lawrimore, J.H., Groisman, P.Y., Speranskaya, N.A., Zhuravin, S.A., Menne, M.J., Peterson, T.C. and Malone, R. 2001. Evaporation chabges over the contiguous United States and the former USSR: A re-assessment: Geophysical Research Letters. 28: 2728.
Jain, S.K. and Vijay Kumar. 2012. Trend analysis of rainfall and temperature data for India. Current Science. 102(1): 37- 49.

Kendall, M. and Gibbons, J. D. 1990. Rank Correlation Methods. $5^{\text {th }}$ ed. Oxford University Press, NY. pp. 803/1803/12.

Kendall, M.G. 1975. Rank Correlation Methods. $4^{\text {th }}$ ed. Charles Griffin, Londan.

Liu, Y., Lu, D., Zhou, X., Li, W. and He, Q., 2001. Characteristics of spatial distribution and yearly variation of aerosol optical depth over China in last 30 years. Journal of Geophysical. Research. 106: 14501-14513.

Sen, P.K. 1968. Estimate of regression coefficient based on Kendall's tau. Journal of American Satistical Association. 63: 1379-1389.

Shenbin, C., Yunfeng, L. and Thomas, A. 2006. Climatic change on the Tibetan Plateau; potential evapotranspiration trends from 1961-2000. Climatic Change. 76: 291-319.

Zailin, H., Xiaoqin, D., Shaoyuan, F., Shaozhong, K. and Guanhua, $\mathrm{H}$. 2013.Effect of climate change on reference evapotranspiration and aridity index in arid region of China. Journal of Hydrology. 492: 24-34.

Zailin, H., Xiaoqin, D., Shaoyuan, F., Shaozhong, K. and Guanhua, H. 2013.Effect of climate change on reference evapotranspiration and aridity index in arid region of China. Journal of Hydrology. 492: 24-34.

\section{How to cite this article:}

Paghadal, A.M., H.D. Rank, G.V. Prajapati, P.H. Rank, P.S. Pipaliya and Pipaliya, J.S. 2019. The Trend Analysis of Various Components of Water Resources System of Ozat River Basin, Gujarat. Int.J.Curr.Microbiol.App.Sci. 8(11): 241-267. doi: https://doi.org/10.20546/ijcmas.2019.811.030 